American University Washington College of Law

Digital Commons @ American University Washington College of

Law

Articles in Law Reviews \& Other Academic Journals

Scholarship \& Research

1993

\title{
Legal Aliens, Local Citizens: The Historical Constitutional and Theoretical Meanings of Alien Suffrage
}

Jamin B. Raskin

American University Washington College of Law, raskin@wcl.american.edu

Follow this and additional works at: https://digitalcommons.wcl.american.edu/facsch_lawrev

Part of the Civil Rights and Discrimination Commons, Constitutional Law Commons, Election Law Commons, and the Immigration Law Commons

\section{Recommended Citation}

Raskin, Jamin B., "Legal Aliens, Local Citizens: The Historical Constitutional and Theoretical Meanings of Alien Suffrage" (1993). Articles in Law Reviews \& Other Academic Journals. 1044.

https://digitalcommons.wcl.american.edu/facsch_lawrev/1044

This Article is brought to you for free and open access by the Scholarship \& Research at Digital Commons @ American University Washington College of Law. It has been accepted for inclusion in Articles in Law Reviews \& Other Academic Journals by an authorized administrator of Digital Commons @ American University Washington College of Law. For more information, please contact kclay@wcl.american.edu. 


\title{
LEGAL ALIENS, LOCAL GITIZENS: THE HISTORICAL, CONSTITUTIONAL AND THEORETICAL MEANINGS OF ALIEN SUFFRAGE
}

\author{
JAMIN B. RASKIN†
}

Citizen: $\quad$ Ia: an inhabitant of a city or town

2a: a member of a state

There is no more invariable rule in the history of society: The further electoral rights are extended, the greater is the need for extending them: for after each concession the strength of democracy increases, and its demands increase with its strength. ${ }^{2}$

\section{INTRODUCTION}

Democracy promises rule by "the people," but the theory of democracy implies no specific set of arrangements for political membership or participation. ${ }^{3}$ In practice, democracies have always deemed whole categories of people unfit to govern, denying them the vote and thus the opportunity to participate in the

* Assistant Professor of Law, Washington College of Law at The American University; A.B. Harvard College 1983; J.D. Harvard Law School 1987. Research for this Article was supported by a grant from the Washington College of Law. I would like to thank Dean Elliott Milstein for his support and the following persons for their comments on this project: Gerald Neuman, Cass Sunstein, Diane Orentlicher, James Boyle, Bernard Corr, Mark Hager, Joan Williams, Linda Bozniak, and Gary Peller. I was also blessed with devoted research assistants, led by Barbara de La Viez, and including Valerie David, Randy Kravis, Carla Markim, and Cate Sutter. This article is dedicated to the late Judith N. Shklar and to the good people of Takoma Park, Maryland.

1 WEBSTER'S THIRD NEW INTERNATIONAL DiCTIONARY 411 (1981).

2 ALEXIS DE TOCQUEVILLE, 2 DEMOCRACY IN AMERICA 10 (Henry Reeve trans., \& Phillips Bradley ed., Knopf 1946) (1840).

3 Most dictionaries define democracy as "government by the people" but do not define "the people." See, e.g., WEBSTER's THIRD NEW INTERNATIONAL DICTIONARY 600 (1981). Abraham Lincoln's elegant and resounding formulation in the Gettysburg Address-"government of the people, by the people, and for the people"-has seized and held the American democratic imagination despite, or perhaps because of, the fact that the exact meaning of "the people" is left unspoken and, therefore, historically dynamic. See GARRY WILLS, LINCOLN AT GETTYSBURG: THE WORDS THAT REMADE AMERICA 127-33, 145-47 (1992) (furnishing an exegesis of the address and arguing that it accomplished an "intellectual revolution" in American political thought by defining the American experiment as "the people's" commitment to the principles of liberty and equality embodied in the Declaration of Independence rather than a compact among sovereign states). 
essential and representative act of democratic politics. ${ }^{4}$ But if "universal suffrage" for all persons living in the governed jurisdiction is not logically required by democratic ideology, through social struggle it has almost always become a political imperative in democratic history. ${ }^{5}$

In American history, the desire to exclude people from political membership on the basis of property, wealth, race, and gender has been overcome by the radical demand to grant the vote to all inhabitants of the governed community. ${ }^{6}$ Taking the form of progressive waves of popular struggle, the political imperative of "universal suffrage" has moved the various levels of the American regime ever closer to the ideal of becoming what $I$ want to call "polities of presence," communities governed by all adults living within them. The circle of voting membership in the democracy has so far widened to incorporate: people without taxable property or

${ }^{4}$ For example, Athenian democracy, the fountain of so many democratic images and hopes, was officially closed to women, slaves, colonial subjects, and aliens. See generally I.F. STONE, THE TRIAL OF SOCRATES (1988). Aristotle thought that "not all those are to be regarded as citizens without whom there would not be a city." ARISTOTLe, The Polrtics, bk. 3, ch. 5, at 93 (Carnes Lord trans., 1984).

${ }^{5}$ Cf. JUDITH N. SHKLAR, AMERICAN CITIZENSHIP: THE QUEST FOR INCLUSION 37 (1991) ("No historically significant form of government or of citizenship is in principle incompatible with the exclusion of large groups of people, but natural-rights theory makes it very difficult to find good reasons for excluding anyone from full political membership in a modern republic.").

${ }^{6}$ The history of suffrage in the United States has been defined by successive waves of political struggle and resistance, culminating in formal political inclusion. The theme of progressive inclusivity in the franchise is common in both constitutional case law and the literature on voting. See, e.g., Reynolds v. Sims, 377 U.S. 533, 555, 586-87 (1964) (noting that "history has seen a continuing expansion of the scope of the right of suffrage in this country" before holding that the temporary reapportionment of the Alabama legislature was "an appropriate . . . exercise of judicial power"); KIRK H. PORTER, A HISTORY OF SUFFrAGE IN THE UNITEd STATES at vii (2d ed. Greenwood Press 1969) (1918) (“[A] vigorous fight has been going on ever since 1776 to secure suffrage for some large and discontented group-ever growing larger and more discontented until it finally embraced the women. And in the wake of this demand the suffrage franchise has expanded slowly, grudgingly, and by compromising steps. The progress still continues in the same laborious fashion."). But see Robert J. Steinfeld, Property and Suffrage in the Early American Republic, 41 STAN. L. REv. 335, 336-37 (1989) (expressing reservations about "this all-too-familiar . . . [Whig] history of the suffrage"). 
income, ${ }^{7}$ African-Americans, ${ }^{8}$ women, ${ }^{9}$ and eighteen-year-olds, ${ }^{10}$ to take the four most prominent categories of those enfranchised after political struggle. ${ }^{11}$

But if the story of expanding American suffrage captures a significant part of our history, there is somewhat more to the picture than meets the eye. As the franchise has expanded over the centuries to take in nearly all adult citizens, one group which voted and participated, at various points over a 150-year period, in at least twenty-two states and territories, lost its historic access to the ballot: inhabitants of individual states who are not citizens of the United States or, to use the reifying but inescapable idiom of immigration law, resident aliens. ${ }^{12}$ Today, with the extraordinary, though still largely unwritten, ${ }^{13}$ history of alien suffrage safely hidden from

7 See generally Chilton Williamson, American Suffrage from Property to DEMOCRACY 1760-1860 (1960) (tracing the dismantling of the property and wealth qualifications).

${ }^{8}$ See U.S. CONST. amend. XV, $\$ 1$.

${ }^{9}$ See U.S. CONST. amend. XIX.

${ }^{10}$ See U.S. CONST. amend. XXVI, $\$ 1$.

11 The best overview of these transformations in the franchise is found in SHKLAR, supra note 5 at 15-19, 25-62 (discussing the four expansions of suffrage in the realm of citizenship). For discussions of specific franchise enlargements, see generally ERIC FONER, RECONSTRUCTION: AMERICA's UNFINISHED REVOLUTION 1863-1877 (Henry S. Commager \& Richard B. Morris eds., 1988) (discussing agitation for the Fourteenth and Fifteenth Amendments and analyzing the efforts during Reconstruction to bring African-Americans into the franchise); LINDA G. FORD, IRON-JAWED ANGELS: THE SUFFRAGE MILTTANCY OF THE NATIONAL. WOMAN's PARTY (1991) (discussing the role of militancy in the coming of women's suffrage); WILLIAM GILLETTE, THE RIGHT TO Vote: POLITICS AND THE PASSAGE OF THE FIFTEENTH AMENDMENT (1965) (discussing the political twists and turns leading up to enactment of the Fifteenth Amendment). To date, there is no apparently thorough historical account of the passage of the Twenty-Sixth Amendment enfranchising 18-year-olds.

12 I am aware of the pejorative, if not extraterrestrial, resonances emanating from the word "alien." Unfortunately, the term possesses a legal significance which makes it difficult to replace in every context. Moreover, the best alternative-"noncitizen"-is misleading since my argument is that people who do not qualify as national citizens can nonetheless be citizens of their state or, more importantly, their local communities. See generally Kevin R. Johnson, A "Hard Look" at the Executive Branch's Asylum Decisions, UTAH L. REV. 279, 281 n.5 (1991) (arguing that the use of the word "alien" in the Immigration \& Naturalization Act is dehumanizing and carries subtly racist connotations).

${ }^{13}$ Legal observers who have ventured into this field have correctly noted the dramatic absence of professional historical accounts of alien suffrage. See Gerald M. Rosberg, Aliens and Equal Protection: Why Not the Right to Vole?, $75 \mathrm{MrCH}$. L. Rev. 1092, 1093-94 (1977) (stating that little has been written on the history of suffrage in the United States, particularly alien suffrage); see also Gerald L. Neuman, "We Are the People": Alien Suffrage in German and American Perspective, 13 MicH. J. INT'L L. 259, 292 n.214 (1992) (citing Rosberg supra, at 1093-94). Regardless of intellectual 
view, the U.S. citizenship voting qualification ropes off the franchise in every American state from participation by non-U.S. citizens. As a marker at the perimeter of the American body politic, the citizenship qualification carries the aura of inevitability that once attached to property, race, and gender qualifications.

In this Article, I will argue that the current blanket exclusion of noncitizens from the ballot is neither constitutionally required nor historically normal. Moreover, the disenfranchisement of aliens at the local level is vulnerable to deep theoretical objections since resident aliens-who are governed, taxed, and often drafted just like citizens-have a strong democratic claim to being considered members, indeed citizens, of their local communities. ${ }^{14}$ Although democratic theory cannot resolve the foundational political question of who belongs to "the people," the ideological traditions of both liberalism and republicanism make available compelling arguments for the inclusion of noncitizens as voters in local elections. ${ }^{15}$ The bedrock hostility of the liberal rights tradition to taxation and governance without representation makes noncitizen voting a logically unassailable, if not clearly mandatory, democratic practice. Republicanism presents a somewhat more complicated picture given its historic compatibility with exclusionary practices, but a progressive commitment to dialogic politics and the constitutive value of participation is arguably vindicated by defining universal suffrage without regard to nation-state citizenship. These arguments are deepened by evolving international norms of community-based democracy and human rights and strengthened by important instrumental considerations relating to the surge in immigration which the United States is currently experiencing.

differences, I am deeply indebted to both of these gifted scholars. Rosberg's article re-opened the question of alien suffrage for our time, and Neuman's work of comparative scholarship is consistently useful and surpassingly provocative. They have made my task much more interesting and have been forthcoming in commenting on the ideas proposed in this Article.

14 The question of participation at the state and national level (these levels are linked by our constitutional regime) presents more difficult problems. See infra part II.D.

${ }^{15}$ I do not mean to suggest that either of these theoretical traditions compels the adoption of alien suffrage. As Morton Horwitz has recently reminded us, abstract theoretical propositions have never decided concrete cases requiring choices about values. See Morton J. HoRwitz, The Transformation of AMERICAN LAW 18701960, at 271 (1992) ("The idea that something concrete really follows from one's abstract position on, say, natural rights versus positivism is widely believed. Yet in American history natural rights has equally served both abolitionists and the defenders of the rights of ownership in human and non-human property."). 
Part I sketches the role alien suffrage has played in American history. The practice figured importantly in our nation-building process ${ }^{16}$ until it was finally undone by the xenophobic nationalism preceding and accompanying World War I. ${ }^{17}$ The state legislatures which enacted alien suffrage policies operated from a paradigm of strong federalism; most believed that, just as the United States had citizens, individual states could have citizens of their own. ${ }^{18}$ Their motivation for extending the ballot to aliens varied according to place and time, but it was always a mixture of instrumental policy and democratic principle. In the eighteenth century, alien voting occupied a logical place in a self-defined immigrant republic of propertied white men: It reflected both an openness to newcomers and the idea that the defining principle for political membership was not American citizenship but the exclusionary categories of race, gender, property, and wealth. ${ }^{19}$ Later, especially in the mid-nineteenth century, many states hoped to encourage rapid settlement by enfranchising aliens; ${ }^{20}$ they knew that aliens were seeking the opportunity to participate in local affairs and the sense of belonging and respect that the ballot symbolized, the sense Judith Shklar has called "citizenship as standing. ${ }^{21}$

From the beginning, however, proponents of alien suffrage also justified the practice on the higher ground of democratic principle, especially natural-rights arguments. The state judicial opinions upholding alien suffrage, ${ }^{22}$ the supportive speeches made in state constitutional conventions, ${ }^{23}$ and various remarks made in the United States Senate thus provide a rich source of principled arguments for reviving alien suffrage today.

Part II provides a constitutional analysis concluding that state enfranchisement of noncitizens is neither forbidden by the Constitution, as is commonly assumed, ${ }^{24}$ nor compelled by it, ${ }^{25}$ as was argued by Gerald Rosberg in an important article published in

\footnotetext{
16 See infra part I.A.

${ }^{17}$ See infra notes $136-37$ and accompanying text.

${ }^{18}$ See infra notes $36-38 \& 82$ and accompanying text.

${ }^{19}$ See infra notes $54-56$ and accompanying text.

${ }^{20}$ See infra notes 87-90, 125-26 and accompanying text.

${ }^{21}$ SHKLAR, supra note 5 , at 3 .

${ }^{22}$ See infra notes 74-81, 277-82 and accompanying text.

23 See infra notes $92-94$ and accompanying text.

24 See infra parts II.A-.C.

25 See infra part II.D.
} 
1977. ${ }^{26}$ Rather, this Article shows that noncitizen suffrage is a franchise issue reserved to the states by Article I of the Constitution. ${ }^{27}$ Furthermore, granting the vote to aliens does not offend the Equal Protection Clause, ${ }^{28}$ the Naturalization Clause, ${ }^{29}$ or any other constitutional principle. ${ }^{30}$

Part III presents the normative argument for reviving alien suffrage at the local level. The argument begins by generalizing oldfashioned democratic principles which were used to justify white male alien suffrage in the American past. ${ }^{31}$ Although these principles did not provide enough armor for alien suffrage to withstand the rise of anti-immigration sentiment at the turn of the century and militant nationalism at the time of World War I, they may yet reemerge in the contemporary context of heavy immigration and international movement toward "[c]ommunity-based democracy." ${ }^{32}$ This movement, following the emergence of a global market and the corresponding dilution of national boundaries, would invite us to treat local governments as "polities of presence" in which all community inhabitants, not just those who are citizens of the superordinate nation-state, form the electorate. Alien suffrage would thus become part of a basic human right to democracy. This logic is already partially at work in Europe, as the proposed Maastricht Treaty for the European community contains a provision for local voting by European nationals in their city of residence regardless of state citizenship. ${ }^{33}$

Part IV canvasses the current status of noncitizen voting in the United States and describes in some detail the experience of the City of Takoma Park, Maryland, which in 1992 became the first American municipality in decades to amend its charter specifically to extend the franchise to noncitizens in local elections. ${ }^{34}$ Takoma Park's experience embodies the cluster of legal and theoretical issues which can emerge when localities attempt to effect this local constitutional change. If the democratic argument for alien suffrage

${ }^{26}$ See generally Rosberg, supra note 13 (reintroducing the issue of alien suffrage in legal debate).

${ }^{27}$ See infra notes 157-64 and accompanying text.

${ }^{28}$ See infra notes $175-87$ and accompanying text.

${ }^{29}$ See discussion infra part II.C.

${ }^{30}$ See discussion infra part II.B.

31 See discussion infra part III.A.

${ }^{32}$ Michael H. Shuman, Dateline Main Street: Courts v. Local Foreign Policies, FOREIGN POLICY, Spring 1992, at 158, 158 (1992).

${ }^{33}$ See infra notes 361-63 and accompanying text.

${ }^{34}$ See infra notes 375-89 and accompanying text. 
in our history can be recaptured and reconstructed, it is possible that Takoma Park will become an early precedent for grass-roots constitutional politics in the twenty-first century.

\section{Alien Suffrage AND tHe CoMplex MEANINGS OF Gitizenship UNDER FEDERALISM: A HISTORICAL SKETCH}

Until it was finally undone by the xenophobic nationalism attending World War $I$, alien suffrage figured importantly in America's nation-building process and in its struggle to define the dimensions and scope of democratic membership. Where alien suffrage was adopted, the practice was seen as conducive to a desired immigration (and assimilation) of foreigners and consistent with basic principles of democratic government. Moreover, the enactment of noncitizen voting laws was widely recognized as permissible within the constitutional regime of electoral federalism. ${ }^{35}$ The class of aliens-or, more precisely, white male aliensexercised the right to vote in at least twenty-two states or territories during the nineteenth century. ${ }^{36}$ After a surge in anti-immigrant emotion at the turn of the century, there was a steady decline in alien suffrage and Arkansas became the last state to abandon noncitizen suffrage in $1926 .{ }^{37}$

As a chapter in the history of American federalism, the period of alien suffrage reflected a conception of states as sovereign political entities. The states with alien suffrage allowed non-U.S. citizens to participate in voting at all levels of American government, thereby turning them, explicitly or implicitly, into "citizens" of the state itself. ${ }^{38}$ Participant states were thus exercising inde-

${ }^{35}$ See infra parts II.A-.B.

${ }^{36}$ See Leon E. Aylsworth, The Passing of Alien Suffrage, 25 AM. POL. ScI. REv. 114, 114 (1931).

${ }^{37}$ See id.

${ }^{38}$ Gerald Neuman has pointed out that the "early examples of alien suffrage were linked with the confusion over the relationship between state and federal citizenship." Neuman, supra note 13, at 293. There is nothing inconsistent with federalism in the idea that states may create state citizens of their own so long as they do not try to confer on any person national citizenship, a power which is the exclusive province of Congress. See U.S. CoNST. art. I, § 8, cl. 4. The Fourteenth Amendment provides only that "[a]1l persons born or naturalized in the United States, and subject to the jurisdiction thereof, are citizens of the United States and of the State wherein they reside." U.S. CONST. amend. XIV, $\$ 1$. Thus, while states may not deprive any born or naturalized U.S. citizen of state citizenship, nowhere does the Fourteenth Amendment, or any other constitutional provision, prevent states from enfranchising, or conferring citizenship for local state purposes on persons not born or naturalized 
pendence from the national government for the purposes of communal political self-definition.

In choosing to confer the rights of political membership on aliens, these states were recognizing meanings of citizenship apart from the notion of mere membership in the nation-state. One meaning, which I would call "citizenship as presence," defined citizens as all those people actually present and participating in the life of the local and state community. In this sense, alien suffrage was simply a recognition of the continuing presence and importance of aliens in American social life. A second meaning, which I would call a "citizenship of integration," reflects the intentional public policy of assimilating aliens to local values and practices. Finally, alien suffrage jurisdictions were acting on a theory of "citizenship as standing." 39 According to the theory of "citizenship as standing," the right to vote is an emblem of public recognition and respect even more than it is an instrument for exercising political power. ${ }^{40}$ Alien suffrage represented a victory for aliens seeking recognition and an improved place in American society. For, as Shklar writes, the "ballot has always been a certificate of full membership in society, and its value depends primarily on its capacity to confer a minimum of social dignity. "41

War has exercised powerful effects on the franchise. Yet, while foreign wars broadened suffrage opportunities for women and African-Americans, ${ }^{42}$ aliens lost ground in two war-related periods of nationalism and anti-immigrant emotion. The War of 1812 reversed the spread of alien suffrage, and the xenophobia surrounding World War I, for all intents and purposes, closed the curtain on the practice. In the wake of World War $I$, the vertical primacy of

in the United States.

${ }^{39}$ SHKLAR, supra note 5, at 3. Shklar identifies three other principal meanings of citizenship: "active participation or "good' citizenship," "citizenship as nationality," and "ideal republican citizenship." Id.

${ }^{40}$ In American history, the struggle for recognition has been closely linked to efforts by various subordinate groups to distance themselves from the status of slaves.

In the four great expansions of the suffrage, slavery was always a presence in the language of political argument. The Colonists rebelling against English rule, the white males disenfranchised by property and tax qualifications, the freedmen after the Civil War, and finally women all protested that they were reduced to the level of slaves if they did not have the vote and equal representation.

Id. at 16.

41 Id. at 2.

42 See id. at 53-62. 
nation-state citizenship was firmly established over citizenship's other possible meanings. There was, however, an exception to the constraining effects of war on alien suffrage: for complex reasons, the North's victory in the Civil War acted as a catalyst for the spread of alien suffrage in the late nineteenth century.

\section{A. Voting Rights for All White Men of Property: Alien Suffrage in the Early Republic}

The practice of noncitizen voting first appeared in the colonies, which generally required only that voters be local "inhabitants or residents, ${ }^{n}$ and not British citizens. ${ }^{43}$ This early liberalism did not reflect universal tolerance, but simply the fact that "the ethnocentrism of the colonial period was primarily religious and only secondarily nationalistic." ${ }^{44}$ Thus, many alien "inhabitants" who met the appropriate property, wealth, race, religion, and gender tests possessed the right to vote in the colonies. For example, French Huguenots voted in South Carolina, where the "electoral law had been so loosely drawn, it was said, that with only a property qualification every pirate of the Red Sea operating from a Carolina base could vote if he wanted to." 45 There was widespread alien voting in the colony's 1701 election, and despite conservative protests, the South Carolina Assembly in 1704 enacted an electoral law which formally allowed voting by aliens. ${ }^{46}$

43 Williamson, supra note 7, at 15. Delaware, Massachusetts, New Hampshire, and Virginia did not even require residence or inhabitation because not all propertyowners necessarily lived on their property. See id.

44 MAURICE R. DAVIE, WORLD IMMIGRATION 37 (1936) (paraphrasing Lawrence Guy Brown).

45 Williamson, supra note 7 , at 53.

${ }^{46}$ See AlBert E. MCKINLEY, THE SUFFrage FranCHISE IN THE THIRTEEN ENGlish COLONIES IN AMERICA 140 (Burt Franklin 1969)(1905). Describing the 1701 election as a "scene of riot, intemperance, and confusion," id. at 137 (citing 1 ALEXANDER HEWATt, AN HISTORICAL ACCOUNT OF THE RISE AND PROGRESS OF THE COLONIES OF SOUTH CAROLINA AND GEORGIA 151 (1779)), several conservative Englishmen from Colleton County filed this complaint with the colonial government:

"[T] he votes of very many unqualify'd Aliens were taken \& enter'd . . . a great number of Servants \& poor \& indigent persons voted promiscuously with their Masters \& Creditors, and also several free Negroes were receiv'd, \& taken for as good Electors as the best Freeholders in the Province. So that we leave it with Your Lordships to judge, whether admitting Aliens, Strangers, Servants, Negroes, \&cc., as good and qualified Voters, can be thought any ways agreeable to King Charles' Patent to Your Lordships, or the English Constitution of Government." 
Neuman has observed that, during the colonial period, "the practices of British nationality law had coexisted with a practice of local naturalization valid only within a particular colony. ${ }^{n 7}$ Thus, the idea emerged that each colony could make citizens of its own and give them the right to vote. But some colonies did not even require inhabitants to be locally naturalized citizens in order to have the franchise. In Pennsylvania, for example, the large "German population evidently voted and held local office, with or without benefit of either private acts of naturalization or the special provincial statute passed in 1742, two years after the imperial Parliament provided for naturalization in the empire as a whole." ${ }^{n 8}$ Alien suffrage survived the Revolution in 1776 as many states granted foreigners state "citizenship," a status which was "given extraterritorial consequences by the privileges and immunities clause of the Articles of Confederation." ${ }^{\text {"49 }}$ Vermont's first Constitution allowed for both the naturalization and enfranchisement of aliens, and the young Commonwealth of Virginia accomplished the same purposes by statute. ${ }^{50}$ In the Commonwealth of Pennsylvania, after only two years of residence, aliens were permitted to vote. ${ }^{51}$ Even though the new federal Constitution delegated to Congress the power to "establish an uniform Rule of Naturalization," ${ }^{52}$ it still "took three decades to settle the exclusivity of the federal power to naturalize to national citizenship, and even thereafter the possibility of state conferral of state citizenship seemingly remained." 53

Id. (quoting WILLIAM J. RIVERS, A SKETCH OF THE History OF SOUTH CAROLINA TO THE ClOSE OR THE PROPRIETARY GOVERNMENT BY THE REVOLUTION OF 1719 app. at $455(1856)$ ). But the newly elected Governor and Assembly, presiding over a coalition of the pro-Anglican Church faction and the immigrant French, rejected appeals for narrowing the electorate, and a similar election occurred in 1703. See id. at 137-38.

47 Neuman, supra note 13, at 292.

48 WILliamSON, supra note 7 , at 174 .

49 Neuman, supra note 13, at 292 (citing James H. KeTtNer, The Development OF AMERICAN CITIZENSHIP, 1608-1870, at 219-24 (1978)).

${ }^{50} \mathrm{See}$ id. at 293-94. Neuman's fine historical reconstruction shows that alien suffrage was both a common and highly contested practice. Vermont ended the practice in 1828, grandfathering in those who were already voting, and Virginia continued to enfranchise and naturalize aliens through the $1840 \mathrm{~s}$.

51 See WILliamson, supra note 7, at 174.

52 U.S. CONST. art. I, $\$ 8$, cl. 4.

53 Neuman, supra note 13, at $292-93$ (citations omitted). Surely the fact that the Constitution defined federal electors as those permitted to vote in the states contributed to the sense that the states' definition of citizenship was primary, or at the very least, concurrently effective with the federal power. For, if winning the right to vote in a state assured participation in national elections, were there any political 
It is crucial to see that the early spirit of political openness toward aliens was perfectly compatible with the exclusionary definition of "the American people as Christian white men of property. ${ }^{54}$ Indeed, when properly cabined within the existing rules of suffrage, alien voting subtly reinforced the multiple ballot exclusions of the time. To exclude aliens from voting would have given rise to the dangerous inference that U.S. citizenship was the decisive criterion for suffrage at a time when the majority of U.S. citizens, including almost all women and substantial percentages of men without property, were categorically excluded from the franchise. ${ }^{55}$ On the other hand, alien enfranchisement reflected the assumption that the propertied white male alien voter would be sufficiently similar to other electors so as not to threaten fundamental cultural and political norms. ${ }^{56}$

If alien suffrage in the early years of the Republic reflected the states' power to define their own electorates and their elevation of

rights of federal "citizenship" not obtainable in the states?

${ }^{54}$ See generally Christopher Collier, The American People as Christian White Men of Property: Suffrage and Elections in Colonial and Early National America, in VOTING AND THE SPIRT OF AMERICAN DEMOCRACY 19 (Donald W. Rogers ed., 1992). The states had mostly carried over the prevailing suffrage rule in the colonies, which was that eligible voters had to own "freeholds" worth a certain amount of money or composed of a certain number of acres. See WILLIAMSON, supra note 7, at 12-13. This rule was premised on the "concept that the freeholders were and should remain the backbone of state and society because they were the repository of virtues not found in other classes." Id. at 3; see also Linda K. Kerber, The Paradox of Women's Citizenship in the Early Republic: The Case of Martin v. Massachusetts, 1805, 97 AM. HIST. REV. 349, 349 (1992) ("The political community fashioned by the American war was a deeply gendered one in which all white adults and a few black adults were citizens but white men's voices were privileged.").

${ }^{55}$ Exact figures are hard to find, but it is clear that most women and many men were excluded from the franchise in the colonial period. Williamson states that we "can accept as relatively correct the view that about 20 percent of the population at that time consisted of adult males, probably a conservative estimate for newer communities on the frontier or in western parts of the colonies." WILLIAMSON, supra note 7 , at 24 . Of the white male adult population, generally 50 to 80 percent appeared to be voters. See id. at 26-31; see also Collier, supra note 54, at 26 (noting that while a small fraction of the citizen population voted in the colonies, the numbers increased substantially after the Revolution).

${ }^{56}$ Although the point should not be overstated, it is somewhat instructive as to the original political meaning of alien suffrage that Chief Justice Taney referred approvingly to the practice several times in the course of his white supremacist opinion in the Dred Scott case, holding that African-Americans could never be U.S. citizens. See infra notes $144-46$ and accompanying text. It is also worth noting in this regard that the demise of alien suffrage took place in the early twentieth century when larger number of immigrants came from Italian, Jewish and Mediterranean stock. 
race, gender, and property over citizenship, the United States Congress used alien suffrage in an instrumental way to produce immigration in the northwest territories. In 1789, the first Congress to convene under the Constitution reenacted the Northwest Ordinance of 1787 to provide for the governance of the territories northwest of the Ohio River. The Ordinance gave freehold aliens who had been residents for two years the right to vote for representatives to territorial legislatures, and gave wealthier resident aliens who had been residents for three years the right to serve in these bodies. ${ }^{57}$ This remarkable willingness to welcome aliens qua aliens into the nascent political enterprise of the new nation continued as Congress supervised the organization of the territories and oversaw their passage into statehood. ${ }^{58}$ In the various congressional acts authorizing the election of representatives to statewide constitutional conventions in Ohio, Indiana, Michigan and Illinois, Congress deliberately extended the right to vote to aliens. ${ }^{59}$ This policy

${ }^{57}$ See Act of Aug. 7, 1789, ch. 8, 1 Stat. 50, 51 n.(a) (1789) (enacting, without major changes, the Congress of the Confederation's Northwest Ordinance). Two classes of people were given the right to hold office in the territorial legislatures: resident owners of 200 acres of land who had been citizens of one of the United States for three years, and aliens who owned 200 acres of land and had lived in the territory for three years. See Neuman, supra note 13, at 295 n.235. The class of electors consisted, similarly, of residents who owned 50 acres of land and were citizens of one of the states, and aliens who owned 50 acres of land and had lived in the territory for two years. See id.

The Ordinance's suffrage provisions were later adopted as part of the organic acts of the Orleans, Michigan and Mississippi Territories. See id. at 295 n.234.

${ }^{58}$ An interesting parallel to American willingness to enfranchise foreigners during this period is found in the French Constitution of June 24, 1793, which also extended the franchise to noncitizens. See Frank M. ANDERSON, THE CoNSTITUTIONS AND OTHER SELECTED DOCUMENTS ILLUSTRATIVE OF THE HISTORY OF FraNCE 1789-1907, at 171 (2d ed. 1981).

${ }^{59}$ See Spragins v. Houghton, 3 Ill. (2 Scam.) 377, 395 (1840) (noting that the several acts of Congress regulating the territories gave aliens "the right of electing and being elected to officen $)$. The court stated:

It will also be further perceived, that while the right of electing and being elected to office is conferred on persons who are neither natives nor naturalized citizens of the United States, these same persons were permitted to become members of the conventions which formed the constitutions of Ohio, Indiana, Michigan, and Illinois; and it is notorious that those constitutions were adopted by a portion of votes given by persons who were not citizens of the United States.

Id. The Spragins court, citing the Ohio act, held:

That all male citizens of the United States, of full age, who resided within the territory one year previous to the day of the election, and who had paid a territorial or county tax; and also all persons having, in other respects, the legal qualifications to vote for representatives in the general assembly of the 
placed its stamp on the political culture of the states that would emerge from the territories. In 1802, for example, the new State of Ohio enfranchised all "white male inhabitants" twenty-one years old who had lived there for one year. ${ }^{60}$

Although aliens thus voted freely in state, federal and territorial elections in many places, their participation in local government was even more common. In 1809, in Stewart v. Foster, ${ }^{61}$ the Pennsylvania Supreme Court gave the basic argument for local noncitizen voting in the course of finding that an alien freeholder, who had lived and paid borough taxes in Pittsburgh for one year, was entitled as a matter of state law to vote in the election of borough officers. ${ }^{62}$ As a threshold matter, the court found it dispositive that the act incorporating Pittsburgh authorized only "citizens" to run as candidates in most elections for local office but gave all taxpaying male "inhabitants" the right to vote. ${ }^{63}$ But the court went on to emphasize that, without the state's policy of inviting immigration, it might be forced to accept the English common law principle that "it is as proper to exclude an alien, as a woman or an infant." 64 But this argument, the court stated:

[I]s not so forcible here, as it would be in England, because Pennsylvania, both under the proprietary government, and since her independence, has held out encouragement to aliens, unknown to the principles of the common law .... I am irresistibly led to the conclusion, that in the view of the legislature, the peace and prosperity of the borough were sufficiently secured, by providing that the officers elected should be citizens, although aliens of a certain description, who from length of residence, and payment of taxes, might be supposed to have a common interest with the other inhabitants, were indulged with the right of voting. ${ }^{65}$

At the same time as the ideology of local alien suffrage was being articulated in cases like Stewart, the War of 1812, which produced a militant nationalism and suspicion of foreigners,

territory, were authorized to choose representative [sic] to form a convention to frame a constitution and state government.

Id. at 394 (citation omitted).

${ }^{60}$ OHIO CONST. of 1802, art. IV, $\$ 1$ (1851); see also infra notes 75-82 and accompanying text (discussing an Illinois case which held that the suffrage provision includes aliens).

612 Binn. 110 (1809).

62 See id. at $118-19$.

${ }^{63}$ See id. at 117-18.

64 Id. at 118 .

${ }^{65} I d$. 
heralded the end of the Revolutionary period of liberal attitudes toward noncitizen voting. ${ }^{66}$ In 1812 , beginning with Louisiana, most newly admitted states, including Indiana (1816), Mississippi (1817), Alabama (1819), Maine (1820), and Missouri (1821), confined the franchise to citizens. ${ }^{67}$ Meanwhile, a number of early states which had permitted alien suffrage, revoked the practice during this same period, changing the "constitutional definition of voters from 'inhabitants' to 'citizens." $"$ "68 In addition to the effects of the "rise of national consciousness' engendered by the War of $1812,{ }^{\prime 69}$ Rosberg suggests that the turn away from alien suffrage may have been due to "the increasing public dismay at the arrival of large numbers of new immigrants who were not of English stock and who were thought incapable of ready assimilation."70

Another factor may have played a role in the eroding commitment to noncitizen voting in this period. If early alien suffrage was ideologically consistent with the property qualification, the "agitation for the abolition of property qualifications ... [ [ which] began shortly after the [War of 1812] ended[,]"71 may have undermined popular support for alien suffrage. The abolition of the property qualification would have meant that, in states with alien suffrage, all male aliens, not simply the property owners and the wealthy, would have the right to vote. Thus, for the first time, alien suffrage states would be extending political membership to a different, and obviously more threatening, class of aliens-those generally deemed unworthy of the ballot.

The new state of Illinois, which continued Congress's territorial policy of alien suffrage, stood out as an exception to the post-War of 1812 trend away from alien suffrage. The Illinois Constitution brought into the franchise "all white male inhabitants above the age of twenty-one years, having resided in the State six months." 72 A challenge to alien suffrage in Iilinois in the 1840 case of Spragins $v$. Houghton ${ }^{73}$ provided an opportunity for the Illinois Supreme Court to canvass the progression of policy motivations which led first the

${ }^{66}$ See Rosberg, supra note 13, at 1096-98.

${ }^{67}$ See id. at 1097.

68 Id. (1929)).

${ }^{69}$ Id. at 1097 (quoting Albert J. MCCULlOCH, SUFFraGe AND ITS PROBLEMS 41

70 Id. at 1097-98.

71 SHKLAR, supra note 5 , at 46.

72 ILL. CONST. of 1818, art. II, $\$ 27$ (1970).

73 Ill. (2 Scam.) 377 (1840). 
United States Congress, and then the framers of the Illinois Constitution, to adopt alien suffrage as a constitutional imperative. ${ }^{74}$

The Spragins court found that it was "well understood" that "the right of suffrage was extended to aliens" in the Northwest Territory "as one strong inducement for emigration. "75 Illinois's framers similarly believed that alien voting would help to "induce a flood of emigration to the state, and cause its early and compact settlement." 76

But the Spragins court also emphasized Congress's historic commitment to the democratic inclusion of that "large portion of the inhabitants of Illinois" who were emigrants from France and Canada. ${ }^{77}$ The court found that the framers of the Illinois Constitution had pursued "the same spirit of justice and liberality" as Congress by deliberately including all "inhabitants" in the democratic process. ${ }^{78}$ The court then articulated a general constitutional preference for democratic inclusion where the simple facts of habitation, residence and common social membership establish a political relationship "between the governed and [the] governing. ${ }^{79}$ According to the court, the Illinois Constitution:

[I]ntended to extend the right of suffrage to those who, having by habitation and residence identified their interests and feelings with the citizen, are upon the just principles of reciprocity between the governed and governing, entitled to a voice in the choice of the officers of the government, although they may be neither native nor adopted citizens. ${ }^{80}$

The court added: "If the right of suffrage be a natural, and not a conventional one, there can be no just cause for abridging it, unless by way of punishment for crime, and under very peculiar circumstances, and for peculiar causes. ${ }^{\text {81 }}$

74 See Spragins, 3 Ill. (2 Scam.) at 402-05. The court found it indisputable, as a matter of both textual interpretation and historical analysis, that the word "inhabitants" in the Illinois Constitution's suffrage provision was designed to include aliens and was not meant to be synonymous with "citizens." Id. at 402-05.

75 Id, at 410 .

${ }^{76}$ Id. at 398 . The court noted, somewhat ironically, that this supposition's "influence on the convention, is believed to be beyond doubt; though its effects and influences may have failed in the extent of its anticipated operations." Id.

77 Id. at 397.

${ }^{78} \mathrm{Id}$.

79 Id. at 408.

${ }^{80} \mathrm{Id}$.

${ }^{81} \mathrm{Id}$. 
In the course of explaining these constitutional choices for alien suffrage, the court invoked the theme of local state citizenship, finding that references in the Illinois Constitution to "citizens" did not change the inclusive meaning of "inhabitants" in the electoral provision. The Court stated: "Now, a person may be, in the ordinary sense of the term, a citizen of this state, but still not a citizen of the United States." 82

\section{B. Expansion Westward and the Wisconsin Solution}

Illinois' democratic argument for alien suffrage attracted no new adherents until Wisconsin's admission to the Union in 1848 revived and transformed the practice of alien suffrage. The framers of Wisconsin's Constitution adopted a modified form of alien suffrage, extending full voting rights only to so-called "declarant aliens""[those] White persons of foreign birth who shall have declared their intention to become citizens, conformably to the laws of the United States on the subject of naturalization." As Neuman notes, this provision took advantage of federal naturalization law, which since 1795 had required aliens seeking citizenship to "first declare under oath to a competent court their intention to apply subsequently for citizenship (known colloquially as 'taking out first papers'), and had postponed eligibility for actual naturalization ('second' or 'final papers') until three years after the declaration. ${ }^{\text {"83 }}$ Neuman observes that such declaration, under federal law, did not deprive the alien of his original nationality, did not legally obligate him to complete the process of becoming a citizen, and did not even require an oath of allegiance to the United States. ${ }^{84}$ The Wisconsin plan would later come under attack for these reasons. ${ }^{85}$

82 Id. at 407.

89 Neuman, supra note 13, at 297.

${ }^{84}$ See id.

${ }^{85}$ In 1918, Kirk Porter, a suffrage historian, ridiculed the Wisconsin declarant alien suffrage provision:

The alien is still an alien in every sense of the word until he is naturalized, and his declaration of intention does not make him partially naturalized .... Men who favored admitting aliens to the suffrage after they had declared their intention labored under all sorts of delusions .... . So here was Wisconsin admitting the subjects of the British king and the king of Prussia to the ballot box to help elect a president of the United States.

PORTER, supra note 6, at 119-20. 
Nonetheless, the declarant alien qualification succeeded in weakening the force of nationalist opposition to alien suffrage by recasting the practice of alien suffrage. It now became, much more clearly, a pathway to citizenship rather than a possible substitute for it: noncitizen voting became pre-citizen voting. Thus, declarant aliens in Wisconsin, those presumably on the "citizenship track," won the right to participate in local, state, and national elections.

The Wisconsin formula of enfranchising aliens, but only those who had declared their intention to become citizens, proved popular as the country continued to push westward in the nineteenth century. The desire for immigration carried noncitizen voting along. ${ }^{87}$ Less than three months after Wisconsin's admission, Congress passed an organic act for the Oregon Territory which embodied the same terms on alien voting. ${ }^{88}$ It was followed in 1849 by a parallel provision in the organic act for the Territory of Minnesota. ${ }^{89}$ Although Congress did not extend voting rights to aliens in the territories of Utah, New Mexico, and California (lands won during the Mexican War), it did include provisions for declarant alien suffrage in the enabling acts of the territories of Washington, Kansas, Nebraska, Nevada, Dakota, Wyoming, and

However, Porter preserved sufficient academic composure to note that: "Although the situation has always been anomalous, it has been unquestionably constitutional." Id. at 121.

${ }^{86}$ Rosberg, supra note 13 , at 1110 .

87 See PORTER, supra note 6, at 113. Porter noted:

For the first time the alien found strong champions; for the first time he was really wanted in certain parts of the country, wanted so badly that inducements were held out to attract him. Up in the Great Lakes region-in Michigan, Indiana, Wisconsin, Illinois, and Minnesota-there were vast, uncultivated tracts of land awaiting exploitation. Most of these states had not been organized very many years and they were eager to grow, to develop their resources, increase their population and their wealth, gain larger representation in Congress, and become important units in the national government. What then could be more logical than to offer the swarming immigrants a hand in the government if they would only come? And a hand in the government meant the right of suffrage even before they were naturalized.

Id.

Porter points out that the influx of immigrants also provoked a backlash, symbolized by the famous Know-Nothing Convention in Philadelphia in September of 1847. See id. at 115 (pointing out, somewhat dubiously, that "the opposition to foreigners exercising the right of suffrage reached its highest point in this party, which maintained an organization until the Civil War").

${ }^{88}$ See Oregon Territorial Government Act, ch. 177, § 5, 9 Stat. 323, 325 (1848).

${ }^{89}$ See Minnesota Territorial Governmental Act, ch. 121, § 5, 9 Stat. 403, 405 (1849). 
Oklahoma. ${ }^{90}$ After achieving statehood, some of these territories preserved the practice of declarant alien suffrage in their state constitutions; others decided to abandon the practice entirely; and a few dropped it but made provisions for grandfathering in noncitizens who were already voting. ${ }^{91}$

In 1850, the delegates to the Michigan state constitutional convention replaced a rather strict citizenship requirement from the 1835 constitution with an amendment which extended the vote to all declarant aliens living in the state for half the federal naturalization waiting period. ${ }^{92}$ A delegate from Detroit, J.H. Bagg, gave a rousing speech on behalf of this measure. ${ }^{93}$ Bagg linked alien suffrage to both democratic and Democratic politics, including his party's attack on "the odious property qualification." Stating his own preference for declarant alien suffrage after only one year's residence, he remarked:

I shall now vote for this section or amendment, and if not successful, for the next most liberal which shall be offered. The progressive spirit of the age requires it,-the progressive spirit of the democratic party requires it,-the democracy of this State requires it, and they must have it .... The Peninsular State is yet the banner State of democracy. This convention is a democratic convention. On us and

${ }^{90}$ See Neuman, supra note 13, at 298 (noting that in "all nine of these territories, Congress imposed the additional requirement of an oath to support the U.S. Constitution").

91 The state constitutions of Minnesota (1857), Oregon (1857), Kansas (1859), Nebraska (1867), North Dakota (1889), and South Dakota (1889) all included declarant noncitizen suffrage, while the constitutions of Nevada (1864), Wyoming (1889), and Oklahoma (1907) rejected it. See Neuman, supra note 13, at 299 n.254 ("Montana and Washington limited their prospective enfranchisement to citizens while grandfathering in declarant aliens.").

92 The 1835 provision enfranchised all white men living in Michigan at the time that the constitution was signed. But, after that date, only white male U.S. citizens who had lived in the state for six months were entitled to vote. Naturalized citizens had to have lived in the country for five years and in Michigan for one year. See Henry A. Chaney, Alien Suffrage, 1 MICH. POL. SCI. Ass'N 130-39 (1894).

${ }^{93}$ See id. at 131-34.

[At the time of the War of 1812], sir, an alien had to undergo a probationary state of 21 years before he could become a citizen of these United States. Now it is different. How has this been brought about? Sir, the Democratic party, the party of progress and of equal rights, believing that democracy was confined to no geographic lines, that no man was consulted as to the location of his birth, determined to get rid of these aristocratic features of our Constitution, which smacked too much of the relics of monarchy, of Great Britain, whose yoke we had just thrown off ....

Id. at 132. 
us alone rests the responsibility of making a democratic constitution. $^{94}$

\section{From the Civil War to World War I: The Expansion and Contraction of Alien Suffrage}

During the period of the 1850 s and 1860 s, alien suffrage played a growing role in the struggle between north and south, with southerners trying to reduce and northerners trying to expand the political influence of immigrants, who were overwhelmingly hostile to slavery (if not necessarily friendly to blacks). ${ }^{95}$ The issue of noncitizen voting became a bone of contention in congressional debate over the laws governing new territories and states. During Senate consideration of the Kansas-Nebraska Act, an amendment was offered to forbid noncitizen voting in the new territories. Pennsylvania Senator Brodhead stated that "I do not feel at liberty to go further than the people of my own state have gone in their Constitution. My state confines the right of voting to citizens of the United States. ${ }^{\text {96 }}$ Although, the debate concluded with Congress deciding not to limit the vote to citizens, it flared up again when Congress considered the Minnesota Statehood Enabling act. ${ }^{97}$

After the Civil War began, the Union's military manpower needs caused the armed forces to turn to aliens for help, ${ }^{98}$ and the

94 Id. at 133 .

95 See Eugene C. MuRdock, ONe Million Men: The Civil War Draft in the NORTH 306 (1971) ("Probably a majority of every nationality group-even the Irishdid favor the Union."); see also Rosberg, supra note 13, at 1116-17 ( " $[\mathrm{N}]$ ] matter how ignorant and stupid the immigrant might be, he was more than likely to be sure of one thing-that he did not believe in holding slaves. He could not discuss states' rights, theories of sovereignty, and nullification, but he was unequivocally opposed to the slaveholder." (quoting PORTER, supra note 6, at 3)); id. ("South Carolina and Georgia want people much but they fear the migrations, and will check them rather than run the chance of importing people who may be averse to slavery." (quoting Congressman King's remark)). Of course, many immigrants were also hostile later to the injustices of the Union draft during the Civil War, and terrible anti-draft rioting broke out in many larger cities, including New York, in 1863. See JOHN W. Chambers II, To RaISE AN ARMY: The DRaft Comes to MOdERn AMERICA 53-54 (1987).

${ }^{96}$ Cong. Globe, 34th Cong., 3d Sess. 809 (1857) (remarks of Sen. Brodhead of Pennsylvania).

${ }^{97}$ See Neuman, supra note 13, at 298-99. The Senate, motivated by southern suspicion of anti-slavery sentiment among immigrants, adopted the Clayton amendment, which would have limited the franchise in the new territories' first elections to citizens only. But the House of Representatives wanted to open elections in the new territories to aliens, and the House prevailed.

98 See MURDOCK, supra note 95, at 305-32; see also ROBERT L. PETERSON \& JOHN 
"foreign-born" came to constitute "nearly 25 percent of the Union Army. ${ }^{99}$ Not all alien soldiers were there voluntarily. In confronting the thorny question of aliens and conscription, the government gradually chose voting as the crucial dividing line between draftable and undraftable aliens. On July 17, 1862, Congress passed the Militia Act, which called for the nine-month enrollment of "all able-bodied male citizens between the ages of 18 and 45 , to be apportioned among the States according to representative population. ${ }^{100}$ The Act empowered the President "to draft citizens into the state militia if that state failed to fill its quota through voluntarism."101 In August, Wisconsin Governor Edward Salomon wrote to Secretary of War Edwin M. Stanton, informing him that approximately half of his state's able-bodied men were aliens, but pointing out that they had already declared their intentions to become citizens and were eligible to vote. Governor Salomon urged that these men not be exempted from the draft. ${ }^{102}$ In his answer, Stanton took the position that the mere declaration of intent to become a citizen did not subject these men to the draft but that declarant aliens who had in fact voted would be draftable. ${ }^{103}$

One such man was Carl Wehlitz, an alien from Prussia living in Milwaukee, who had declared his intention to become a U.S. citizen and had exercised his right to vote. ${ }^{104}$ After he was drafted under Stanton's interpretation of the Militia Act, Wehlitz challenged his conscription in court, arguing that, on its terms, the Militia Act

A. HUDSON, FOREIGN RECRUITMENT FOR UNION FORCES, CIVIL WAR HISTORY 176-89 (1961). On the North's constant search for military manpower during the Civil War and the history of conscription during this period, see generally CHAMBERs, supra note 95 , at $47-58$ (describing the events leading up to conscription during the Civil War); JAMES W. GEARY, WE NEED MEN: THE UNION DRAFT IN THE CIVIL WAR (1991) (same); EUGENe C. MURDOCK, Patriotism LimTted 1862-1865: THE CIVIL WAR DRAFT AND THE BOUNTY SYSTEM (1967) (same).

99 CHAMBERS, supra note 95 , at 49.

100 Joseph C. DugGan, The Legislative and Statutory Development of the FEDERAL CONCEPT OF CONSCRIPTION FOR MILITARY SERVICE 22 (1946).

101 CHAMBERS, supra note 95 , at 48.

102 See MURDOCK, supra note 95, at 308. Murdock points out that later in the fall, aliens were drafted in Cleveland, Ohio, which led to a controversy over whether they could be released upon habeas corpus, which had been suspended in military cases by President Lincoln. See id. Governor David Tod tried to prevail upon Secretary Stanton "to instruct commanders of all rendezvous camps to release men claiming alienage and thus avoid a confrontation between civil and military officers." Id.

${ }^{103}$ See id.

${ }^{104}$ See In re Wehlitz, 16 Wis. 468, 468-69 (1863). 
applied only to "citizens" and, as a legal alien, he was therefore not draftable. ${ }^{105}$

In January of 1863, the Wisconsin Supreme Court unanimously rejected Wehlitz' claim. ${ }^{106}$ Justice Paine noted that a system of bifurcated citizenship is inevitable in federalism:

Under our complex system of government there may be a citizen of a state who is not a citizen of the United States in the full sense of the term. This result would seem to follow unavoidably from the nature of the two systems of government. ${ }^{107}$

After finding that the word "citizens" as used by Congress could apply to both U.S.-defined citizens and state-defined citizens, Justice Paine turned to the question of whether declarant aliens who had exercised the right to vote in Wisconsin were in fact citizens of the state. He acknowledged that:

It may be possible for the state to confer the right of voting on certain persons without making them citizens, yet I should think it would require very strong evidence of a contrary intention to overcome the inference of an intention to create a citizenship when the right of suffrage is conferred. ${ }^{108}$

105 See id. at $469-70$.

106 See id. at 480 .

${ }^{107}$ Id. at 470-71. Justice Paine found definitive support for this point in the then recent U.S. Supreme Court's decision in Dred Scott $v$. Sandford. See id. at 470-72. Justice Paine wrote:

"The [C]onstitution has conferred on [C]ongress the right to establish an uniform rule of naturalization, and this right is evidently exclusive, and has always been held by this court to be so; consequently, no state, since the adoption of the [C]onstitution, can, by naturalizing an alien, invest him with the rights and privileges secured to a citizen of a state under the federal government, although so far as the state alone was concerned he would undoubtedly be entitled to the rights of a citizen, and clothed with all the rights and immunities which the [CJonstitution and laws of the state attached to that character."

Id. at 472 (quoting Dred Scott v. Sandford, 60 U.S. (19 How.) 393, 405-06 (1856) (alteration in original)). This point has long been well-accepted by the states. See, e.g., Leche v. Fowler, 6 So. 602, 602 (La. 1889) ("But a person may be a citizen of a particular state and not a citizen of the United States. To hold otherwise would be to deny to the state the highest exercise of its sovereignty .... .").

${ }^{108}$ In re Wehlitz, 16 Wis. at 473 . The Court then drew upon Justice Curtis's dissenting opinion in Dred Scott: "But further, though as I shall presently more fully state, I do not think the enjoyment of the elective franchise essential to citizenship, there can be no doubt it is one of the chiefest attributes of citizenship ...."Id. (quoting Dred Scott v. Sandford, 60 U.S. (19 How.) at 581 (Curtis, J., dissenting)). 
In a political sense, he argued, "the word citizen implies the possession of political rights. ${ }^{109}$

Justice Paine then found that "there is no room for doubt that it was the intention to confer upon [declarant aliens who had voted] the full rights of state citizenship. ${ }^{110}$ Aliens had not only been included in the state constitutional drafting process but were granted the right to vote and run for most public offices by the Wisconsin Constitution. ${ }^{111}$ If the right to participate in politics does "not indicate an intention to create them citizens of the state," Justice Paine observed, "it is difficult to imagine from what such an intention could be inferred." ${ }^{112}$ Thus, he concluded, "[if] the liability of this petitioner to be drafted depended upon the meaning of the word 'citizen' in our state law, I should have no hesitation in saying that he was liable."113 Justice Paine closed his opinion by reiterating his belief in the mutual ties which knit together all voting citizens of Wisconsin, including those deemed to be "aliens."114

The inadequacies of the Militia Act ${ }^{115}$ eventually led Congress

\section{${ }^{109} \mathrm{Id}$. at 473 .}

${ }^{110} \mathrm{Id}$. at 474 .

111 See id.

112 Id.

${ }^{113} I d$. at 477. On the question of Congressional intent, Justice Paine found that "citizen" in the draft law of July 17,1862 was intended to incorporate state definitions of who the citizens were. See id. at 479-80. He supported this conclusion by noting that Congress had enacted another statute providing for immediate naturalization of alien volunteers upon an honorable discharge after the war. See id. at 479-80. Justice Paine then asked rhetorically:

Can it be possible, that [C]ongress, anxious to fill the armies of the Union, and while passing one act to induce entire aliens, who had never declared their intentions at all, to enlist, intended, in another act passed at the same time, to exclude from liability to military duty, by the use of the word 'citizen,' those who had . . . become citizens of the state, and taken a part in the election of the highest officers of the United States?

Id. at 480 .

114 See id. at 480-81. Justice Paine noted:

[Aliens] have enjoyed the privileges and protection of citizens; they have filled the offices, taken part in the enactment of state laws, and had an equal voice with others in the election of the officers and the enactment of the laws of the United States. They have found free homes among us, under our government established upon the principles of civil and religious liberty and equality of rights among men. They have shared our prosperity when we were prosperous and happy, and, by every principle of justice and every sentiment of honor, they ought to share the burdens in this hour of calamity and trial.

Id.

${ }^{115}$ See generally DUGGAN, supra note 100, at 20-23 (describing the history leading 
to pass the Enrolment Act of March 3, 1863. ${ }^{116}$ This Act, often described as the first precedent for the modern selective service system, ${ }^{117}$ included in the draft males between the ages of twenty and forty-five "of foreign birth who shall have declared on oath their intention to become citizens."118 Suddenly, many aliens who had declared their intentions to become citizens now wanted to renounce their plans. ${ }^{119}$ On May 8, 1863 President Lincoln issued a proclamation giving such persons sixty-five days to exit the country or, at the lapse of this period, face the draft. ${ }^{120}$ Significantly, however, all declarant aliens who had already voted were excluded from this offer and could not renounce their declarations of intent. ${ }^{121}$ Thus, any alien who had voted in the United States was subject to the draft immediately, along with U.S. citizens. Aliens trying to escape military service were required to appear before their draft enrollment boards and show "that they had never voted in this country. ${ }^{n 22}$

While the North mobilized aliens to fight for the Union at the outset of the war, southern opposition to alien suffrage deepened. Delegates to the Confederate constitutional convention in Montgomery, Alabama in 1861 chose to do what the original American Founders had not: ban alien voting as a matter of constitutional law. ${ }^{123}$ Article I, Section 2 of the Constitution of the Confederate States, which describes the powers and duties of the House of Representatives, follows precisely the parallel provisions in the United States Constitution except that it explicitly confines the franchise to citizens:

The House of Representatives shall be composed of members chosen every second year by the people of the several States; and the electors in each State shall be citizens of the Confederate States, and

up to Militia Act).

116 Enrolment Act, ch. 75, 12 Stat. 731 (1863).

117 See DuGGaN, supra note 100, at 23.

118 MURDock, supra note 95, at 308 (quoting Enrolment Act, ch. 75, 12 Stat. at 731).

${ }^{119}$ See id. at 309.

120 See id.

121 See id.

122 Id. In Massachusetts, Provost Marshal Samuel Stone, responsible for administering the draft in the Eighth District, required every alien claiming exemption from the draft "to present a certificate from his town or city clerk showing that he had never voted or claimed the right to vote." Id. at 312.

${ }^{123}$ See MARShall L. DeROSA, The CONFEDERATE CONSTITUTION OF 1861, at 73-75 (1991). 
have the qualifications requisite for electors of the most numerous branch of the State Legislature; but no person of foreign birth, not a citizen of the Confederate States, shall be allowed to vote for any officer, civil or political, State or Federal. ${ }^{124}$

The two italicized passages appear to be legally redundant, but the first was probably intended to make clear that Northerners were excluded from participation in Confederate elections, while the latter was evidently designed to disenfranchise non-American foreigners resident in Confederate states. It is ironic that the Confederacy, which was conceived ideologically in opposition to federal control over state affairs, constitutionally foreclosed the option of alien suffrage to the states and localities.

After the Civil War, noncitizen voting recaptured its lost ground as an electoral practice. At least thirteen new states adopted declarant alien suffrage, "all of them in the South or West and all of them evidently anxious to lure new settlers."125 A number of the former Confederate states formed part of this trend as the Reconstruction governments of Alabama, Florida, Georgia, South Carolina, and Texas included provisions for declarant alien suffrage in their Constitutions. ${ }^{126}$ There are a number of plausible explanations for this phenomenon which await treatment by a historian to determine their relative weight. Some of the southern states may have been motivated by the progressive attitudes of Reconstruction and a corresponding eagerness to inject new blood into the postslavery South. This desire to encourage immigration would have constituted a fairly typical motivation for alien suffrage, although designed more for political than economic purposes.

A second and related possibility is that it was seen as only fair to grant the vote to white male aliens, many of whom had fought for, and indeed been drafted by, the North during the Civil War. ${ }^{127}$ Shklar explains that suffrage history is repeatedly marked

124 CONFEDERATE CONST., art. I, § 2, cl. 1 (1861) (emphasis added). I am indebted to Gerald Neuman for directing me to this fascinating point about the Confederate Constitution.

${ }^{125}$ Rosberg, supra note 13, at 1099. Unfortunately, the historical record is somewhat spotty and inscrutable. No general history of noncitizen voting has ever been written, and as Rosberg points out, not all original sources are completely trustworthy. Furthermore, "[f]ew of the commentators make an effort to identify the particular states that allowed aliens to vote." Id. at n.36. Rosberg also points out that some states may have enacted a state statute, as opposed to a constitutional provision, that granted aliens the right to vote. See id.

${ }^{126}$ See Neuman, supra note 13 , at $299 \&$ n.258.

127 One federal statute had already been interpreted as granting citizenship to 
by returning soldiers demanding and obtaining the right to vote as the just reward for their services and "the most basic and characteristic political act of the citizen-soldier. ${ }^{n 128}$ Surely this logic, operating fiercely at the time with regard to blacks, did not escape the notice of alien veterans, who had fought for the blacks' freedom. ${ }^{129}$ Finally, a more sobering interpretation of the move to alien suffrage is that the South had a great need to attract a cheap immigrant labor force in the wake of slavery's abolition. ${ }^{130}$

At any rate, the spread of noncitizen voting after the Civil War renewed the vitality of the practice. In 1894, a political scientist hostile to alien voting attributed recent statewide election results in Wisconsin and Illinois to "the weight of a foreign element"131 and also described foreign newcomers as the heart of the Tammany political machine which "names a president, and in some degree controls an administration." 132 By the time the nineteenth century came to a close, according to Rosberg, "nearly one-half of the states and territories had some experience with voting by aliens, and for some the experience lasted more than half a century." 133

The late nineteenth century revival of alien suffrage, launched by Wisconsin and accelerated by the defeat of the Confederacy, came to a halt at the turn of the twentieth century, when antiimmigration feeling ran very high. Alabama stopped allowing aliens to vote by way of a constitutional change in 1901, followed by Golorado in 1902, Wisconsin in 1908, and Oregon in 1914. ${ }^{134}$

aliens who had volunteered for service and received honorable discharges without requiring any previous declaration of intention or previous residence of more than one year. See In re Wehlitz, 16 Wis. 468, 480 (1863).

128 SHKLAR, supra note 5 , at 45.

${ }^{129} \mathrm{Id}$. at 52. Shklar noted:

The black man could, moreover, now claim to be a genuine citizen-soldier after his services in the Civil War. "It is dangerous to deny any class of people the right to vote. But the black man deserves the right to vote for what he has done, to aid in suppressing the rebellion, both by fighting and by assisting the Federal soldier wherever he was found. He deserves to vote because his services may be needed again,' noted Douglass. 'If he knows enough to shoulder a musket and to fight for the flag, fight for the government, he knows enough to vote."

Id. (quoting Frederick Douglass) (footnote omitted).

${ }^{130}$ For a more complete discussion of the economic needs of the South, see generally, FONER, supra note 11, at 124-75.

131 Chaney, supra note 92, at 196.

$132 \mathrm{Id}$. at 137.

133 Rosberg, supra note 13, at 1099.

${ }^{134}$ See Aylsworth, supra note 36, at 115. 
"With the quickening tempo of war, the enlightened tactic of education for immigrants steadily gave way to the harsh technique of repression." 135 The demise of alien suffrage was hastened by the "frantic and overreactive days of the First World War when attitudes of parochialism and fear of the foreigner were the order of the day. "136 Just as the nationalism unleashed by the War of 1812 helped to reverse the alien suffrage policies inherited from the late eighteenth century, the hysteria attending World War I caused a sweeping retreat from the progressive alien suffrage policies of the late nineteenth century. ${ }^{137}$

In 1918, Kansas, Nebraska, and South Dakota all changed their constitutions to purge alien suffrage, and Texas ended the practice of noncitizen voting in primary elections by statute. ${ }^{138}$ These changes apparently came on the heels of great and, as one observer remarked wryly, quite belated agitation in the press about the horrors of aliens voting. ${ }^{139}$ The momentum for cleansing state law of alien suffrage provisions continued as Indiana and Texas joined the trend in 1921, followed by Mississippi in 1924 and, finally, Arkansas in 1926. ${ }^{140}$ In 1931, a political scientist noted: "For the first time in over a hundred years, a national election was held in 1928 in which no alien in any state had the right to cast a

135 David M. KenNedy, OVer Here: The First WORLd WAR AND AMERICAN SOCIETY 66 (1980).

${ }_{136}$ Ambach v. Norwick, 441 U.S. 68, 82 (1979) (Blackmun, J. dissenting) (holding that a New York statute forbidding permanent certification as a public school teacher for noncitizens who have not manifested an intention to apply for citizenship does not violate the Equal Protection Clause of the Fourteenth Amendment).

${ }^{137}$ See JOHN BRAEMAN ET AL., CHANGE AND CONTINUITY IN TWENTIETH CENTURY AMERICA: THE 1920s, at 229 (1968) (discussing the post-World War I anti-immigrant frenzy). "Such was the peril, it was not enough to bar future immigration or patiently instruct foreigners in the meaning of Americanism. Heroic surgery was immediately required to cut out the cancerous growth. The 'Great Red Scare' was a time of unparalleled intimidation, suppression, imprisonment, deportation-at the local, state, and federal level ...."Id. Aliens were also special targets of the so-called Palmer raids in 1920, when Attorney General A. Mitchell Palmer conducted an indiscriminate nationwide round-up of more than 4,000 suspected radicals, hundreds of whom were deported. See RONALD SANDERS, SHORES OF REFUGE 380 (1988) (chronicling the fear of Communist infiltration and other post-WWI concerns leading to restrictions).

138 See Aylsworth, supra note 36, at 115 .

${ }^{139}$ See PORTER, supra note 6, at $121 \mathrm{n} .1$ ("The press in various parts of the country has become excited over this situation at the present time (February, 1918), and many people seem to think that a startling discovery has been made, for aliens can now vote in seven states of the Union. Certainly it cannot be considered a novel situation, for aliens have voted for congressmen somewhere in the United States for seventy years.").

${ }^{140}$ See Aylsworth, supra note 36 , at $115-16$. 
vote for a candidate for any office-national, state, or local."141 Alien suffrage was pronounced dead and forever lost to our polity: "Because of a reversal of opinion by the state supreme court, alien suffrage in Arkansas became illegal in 1926, and the last vestige of this political anomaly passed from our election system, doubtless never to return." 142

\section{Constitutional Permission for Noncitizen Voting}

During the long history of alien suffrage, neither the Supreme Court nor any lower federal court or state court ever found the practice unconstitutional. On the contrary, numerous state courts explicitly or implicitly endorsed noncitizen voting. ${ }^{143}$ Although the Supreme Court was never forced to decide the issue directly, it explicitly and repeatedly signalled its acceptance of the practice. The Court made its first declaration on the subject in the infamous Dred Scott case in the course of distinguishing between "the rights of citizenship which a State may confer within its own limits, and the rights of citizenship as a member of the Union. ${ }^{\text {144 }}$ The Court stated that "[e]ach State may still confer [all the rights and privileges of the citizen of a State] upon an alien, or any one it thinks proper, or upon any class or description of persons; yet he would not be a citizen in the sense in which that word is used in the Constitution of the United States. ${ }^{145}$ And, again, later the Court noted that "in some of the States of the Union foreigners not naturalized are allowed to vote. ${ }^{n 146}$

The Court's observations about the permissibility of alien voting survived the enactment of the Fourteenth Amendment even if its central holding-that African-Americans could not be "citizens" within the meaning of the federal Constitution-did not. In 1874, the Court in Minor $v$. Happersett ${ }^{147}$ cited the practice of noncitizen voting for the proposition that citizenship and suffrage are independent legal categories which do not necessarily imply one another. ${ }^{148}$

141 Id. at 114 .

142 Id.

143 See supra notes 104-14 and accompanying text.

144 Dred Scott v. Sanford, 60 U.S. (19 How.) 393, 405 (1856).

$145 \mathrm{Id}$

146 Id. at 422.

14788 U.S. (21 Wall.) 162 (1874).

148 In Minor, a native-born white woman resident in the state of Missouri, argued that the disenfranchisement of women by Missouri's Constitution violated the 
In Minor, the Court rejected a woman's claim that Missouri's exclusion of women from the franchise violated her Fourteenth Amendment equal protection rights as a citizen of the state and the United States. The Court found that voting was never a necessary incident of citizenship and that "the Constitution has not added the right of suffrage to the privileges and immunities of citizenship as they existed at the time it was adopted." 149 Canvassing the history of wealth, income, gender, property, race, age, and residency qualifications, Chief Justice Waite, writing for a unanimous court, found it incontrovertible that "all the citizens of the States were not invested with the right of suffrage. ${ }^{n 150} \mathrm{He}$ then made the obverse point that, if in fact not all citizens were voters, neither were all voters citizens:

Besides this, citizenship has not in all cases been made a condition precedent to the enjoyment of the right of suffrage. Thus, in Missouri, persons of foreign birth, who have declared their intention to become citizens of the United States, may under certain circumstances vote. The same provision is to be foundin

Fourteenth Amendment by abridging the privileges and immunities attendant to her citizenship. See Minor, 88 U.S. at 165 . The Supreme Court readily acknowledged that "women have always been considered as citizens the same as men" and stated that Minor's citizenship preceded and, therefore, did not depend upon ratification of the Fourteenth Amendment in 1867. See id. at 169-70. The real question, the Court stated, was therefore not whether a woman is a United States citizen but whether "the right of suffrage is one of the necessary privileges of a citizen of the United States." Id. at 170. To this question, the Court first found that the Fourteenth Amendment had added no new "privileges and immunities" to the rights of the citizenry. Id. at 171. It then canvassed the history of state suffrage at the time the Constitution was adopted and determined that many full-fledged citizens were excluded from voting by virtue of gender, property, age, wealth, income, and residency qualifications. See id. at 172-73. The Court contended further that, if suffrage were a privilege and immunity of citizenship, the Fifteenth Amendment guarantee that citizens would not be denied the right to vote on account of race would be completely redundant and unnecessary. See id. at 175. In adducing further evidence for its position that citizenship and suffrage are not necessary complements, the Court then invoked the history of alien suffrage. See id. at 176-78.

The Court obviously begged the question of whether a state could, consistent with the Fourteenth Amendment, extend the privilege of voting to male citizens but not female citizens. It was not a Supreme Court decision but rather the Nineteenth Amendment to the Constitution, ratified in 1920, which overturned the Court's formalistic and tautological approach to the exclusion of women from suffrage. See U.S. CONST. amend. XIX, $\$ 1$ ("The right of citizens of the United States to vote shall not be denied or abridged by the United States or by any state on account of sex.").

149 Minor, 88 U.S. at 171.

${ }^{150} \mathrm{Id}$. at 176. 
the constitutions of Alabama, Arkansas, Florida, Georgia, Indiana, Kansas, Minnesota, and Texas. ${ }^{151}$

Thus, more than one hundred years ago, in the context of widespread alien voting, the Supreme Court clearly indicated its approval of the practice.

This passage was no lone shot in the dark. In 1904, the Supreme Court briefly revisited the topic of noncitizen voting and gave an even more explicit endorsement of its constitutionality. The occasion was the case of Pope $v$. Williams, ${ }^{152}$ which upheld, against equal protection and general constitutional attacks, a Maryland statute requiring new residents to make a declaration of intent to become Maryland citizens one year before registering to vote. ${ }^{153}$ In the course of emphasizing that "the privilege to vote in a State is within the jurisdiction of the State itself, to be exercised as the State may direct, and upon such terms as to it may seem proper, provided, of course, no discrimination is made between individuals in violation of the Federal Constitution, 154 Justice Peckham observed: "The State might provide that persons of foreign birth could vote without being naturalized, and, as stated by Mr. Chief Justice Waite in Minor $v$. Happersett, such persons were allowed to vote in several of the States upon having declared their intentions to become citizens of the United States." 155 As recently as 1973, the Supreme Court has remarked that "citizenship is a permissible criterion" for limiting voting rights, and thus, implicitly, not a compulsory one. ${ }^{156}$

The Supreme Court's periodic remarks assuming the legitimacy of alien suffrage reflect a proper reading of the constitutional regime governing elections. The Constitution prescribes no specific qualifications for voting in state elections and simply borrows from state-created suffrage qualifications to define the federal electorate. Article I, Section 2 provides that members of the House of Representatives shall be chosen "by the People of the several States, and the Electors in each State shall have the Qualifications requisite for Electors of the most numerous Branch of the State Legisla-

151 Id. at 177.

152193 U.S. 621 (1904).

153 See id. at 632.

154 Id.

155 Id. at $632-33$.

156 Sugarman v. Dougall, 413 U.S. 634, 649 (1973) (striking down, on equal protection grounds, a complete ban on aliens working in the New York Civil Service) (emphasis added). 
ture." ${ }^{157}$ The Seventeenth Amendment similarly provides that United States Senators shall be elected "by the people" of the states and that the "electors in each State shall have the qualifications requisite for electors of the most numerous branch of the State legislatures." 158 As the Supreme Court stated in Minor: "The United States has no voters in the States of its own creation. The elective officers of the United States are all elected directly or indirectly by State voters. 159 The states have accordingly fixed the qualifications for voting, ${ }^{160}$ and noncitizens enfranchised at the state level in earlier times were also thereby permitted to vote for U.S. Representatives, Senators, and Presidents in national elections. ${ }^{161}$

The argument that the Constitution does not forbid noncitizen suffrage is bolstered by the Constitutional architecture governing the election of federal officers. In designing requirements for holding federal office, the Framers showed that they knew how to impose U.S. citizenship as a condition for political participation when they wanted to. The Constitution provides that: "No Person except a natural born Citizen, or a Citizen of the United States, at the time of the Adoption of this Constitution, shall be eligible to the Office of President ...." ${ }^{162}$ This stringent citizenship requirement was loosened a bit for members of the House of Representatives, each of whom, it was decided, must be for "seven Years a Citizen of the United States, ${ }^{163}$ and U.S. Senators, each of whom must be "nine Years a Citizen of the United States." 164 It can be safely concluded from the juxtaposition of the Framers' specific and

157 U.S. CoNST. art. I, § 2, cl. 1.

158 U.S. CONST. amend. XVII.

159 Minor v. Happersett, 88 U.S. (21 Wall.) 162, 170 (1874).

${ }^{160}$ See Lassiter v. Northampton County Bd. of Elections, 360 U.S. 45, 50 (1959) ("The States have long been held to have broad powers to determine the conditions under which the right of suffrage may be exercised ...."). Today, of course, it is well accepted that "the Framers of the Constitution intended the States to keep for themselves, as provided in the Tenth Amendment, the power to regulate elections." Oregon v. Mitchell, 400 U.S. 112, 124-25 (1970) (footnote omitted). See also Carrington v. Rash, 380 U.S. 89 (1965) (holding that a state can impose reasonable residence requirements for voting, but it cannot, under the Equal Protection Clause, deny the ballot to a member of the armed services); THE FEDERALIST NO. 52 (James Madison) (discussing in part the need for states to determine the right of their respective inhabitants to suffrage independently of each other).

161 See Aylsworth, supra note 36, at 114-16.

162 U.S. CONST. art. II, $\$ 1$, cl. 5.

163 U.S. CONST. art. I, $\$ 2$, cl. 2.

${ }^{164}$ U.S. CoNST. art. I, \& 3, cl. 3. 
varying constitutional conditions for federal office-holding and their complete silence as to a citizenship qualification for federal voting that they did not intend to create a U.S. citizenship suffrage qualification.

Given the permission for noncitizen voting implicit in the Constitutional provisions governing elections, it is necessary to question whether any other Constitutional provisions implicitly impose limits on the practice. Specifically, we must ask whether alien suffrage is consistent with the principles of republicanism and one person-one vote, ${ }^{165}$ the various suffrage amendments, ${ }^{166}$ and the Naturalization Clause. ${ }^{167}$

\section{A. Principles of Republicanism and Equal Voting Weight}

There is, no doubt, an argument to be had about whether noncitizen voting is consistent with republican theory, but the practice does not offend the Republican Guaranty Clause. Since its seminal 1849 decision in Luther $v$. Borden, ${ }^{168}$ the Supreme Court has consistently found that the republicanism of a state government, institution, or practice is a non-justiciable political question reserved to Congress, or that the challenged practice is not, on its merits, offensive to the Guaranty Clause. ${ }^{169}$ In Luther, the court refused

165 Relevant provisions are the Republican Guaranty Clause, whose significance is minimal; Article I, Section 2, which has been read to establish the principle of one person-one vote in Congressional elections; and the Fourteenth Amendment's Equal Protection Clause, which requires one person-one vote principles in state legislative elections. See U.S. CoNST. art. IV, § 4; U.S. CoNST. art. I, § 2; U.S. CoNST. amend. XIV.

166 The Fifteenth Amendment forbids suffrage discrimination "by the United States or by any State on account of race, color, or previous condition of servitude." U.S. CONST. amend. XV, § 1 . The Nineteenth Amendment forbids suffrage discrimination "by the United States or by any State on account of sex." U.S. CoNST. amend. XIX, § 1 . The Twenty-Fourth Amendment forbids suffrage discrimination "by the United States or any State by reason of failure to pay any poll tax or other tax." U.S. CoNST. amend. XXIV, § 1. The Twenty-Sixth Amendment secures the right to vote for all citizens who "are eighteen years of age or older" against federal or state denial or abridgement "on account of age." U.S. CONST. amend. XXVI, § 1.

167 U.S. CONST. art. I, § 8.

16848 U.S. (7 How.) 1 (1849).

169 As the Court stated:

If the legislature of the State has the power to create and alter school districts and divide and apportion the property of such districts ... the action of the legislature [in combining preexisting local school districts into a single district] is compatible with a republican form of government even if it be admitted that section 4, Article IV, of the Constitution applies to the creation of, or the powers or rights of property of, the subordinate 
to designate, between the competing incumbent and insurgent regimes of Rhode Island, which was the sovereign republican government, stating that the Guaranty Clause left such a task to Congress only. ${ }^{170}$ The Court also found that the incumbent government's declaration of martial law, though justiciable, did not offend the Guaranty Clause. ${ }^{171}$ The Court has since refrained from striking down specific governmental practices alleged to deprive citizens of their right to a republican form of government. ${ }^{172}$ There is no reason to think that the federal courts would break from this solid line of precedent to find that the institution of noncitizen voting by a state violates the Guaranty Clause. ${ }^{173}$ This is an especially compelling conclusion given the

municipalities of a State.

Attorney Gen. of Michigan v. Lowrey, 199 U.S. 233, 239 (1905); see also Forsyth v. Hammond, 166 U.S. 506, 520 (1897); Luther v. Borden, 48 U.S. (7 How.) 1 (1849).

${ }^{170}$ See Luther, 48 U.S. (7 How.) at 42.

171 See id. at 43.

172 In 1897, the Court found that state legislative (as opposed to the challenged state judicial) control over the territorial boundaries of a municipal corporation "is not one of the essential elements of a republican form of government which, under section 4 of Article 4 of the Constitution, the United States are bound to guarantee to every State in this Union." Forsyth v. Hammond, 166 U.S. 506, 519 (1897). In 1912, the Court rejected a challenge by a corporation to Oregon's initiative and referendum law, by which certain corporate taxes were imposed. See Pacific States Tel. \& Tel. Co. v. Oregon, 223 U.S. 118 (1912). The plaintiff argued that the initiative law and the tax measure passed under it "violate the right to a republican form of government which is guaranteed by $\$ 4$ of Art. IV of the Federal Constitution." Id. at 120-21. The Court held that the matter of whether the popular initiative was a "republican" institution was for Congress to decide. See id. at 149-51. The Court stated it could not simply:

substitute its judgment as to a matter purely political for the judgment of Congress on a subject committed to it and thus overthrow the Constitution upon the ground that thereby the guarantee to the States of a government republican in form may be secured, a conception which after all rests upon the assumption that the States are to be guaranteed a government republican in form by destroying the very existence of a government republican in form in the Nation.

Id. at 142.

${ }^{173}$ But see Texas v. White, 74 U.S. (7 Wall.) 700, 721 (1868) (defining a state generally as "a political community of free citizens, occupying a territory of defined boundaries, and organized under a government sanctioned and limited by a written constitution, and established by the consent of the governed."), rev'd on other grounds, Morgan v. United States, 113 U.S. 476 (1885). It is highly doubtful that this general language, not directed at the question of alien suffrage, would be controlling. At any rate, the word "citizens" here may have an ambiguous meaning, referring not necessarily to U.S. citizens, but citizens of the states. 
mainstream history of alien suffrage and the significant role Congress played in spreading the practice. ${ }^{174}$

Alien suffrage also does not offend the basic republican principle of one person-one vote because aliens can be persons within the meaning of this formulation. If the requirement of one person-one vote, which was extended to local government elections in Avery $v$. Midland, ${ }^{175}$ meant one citizen-one vote, then noncitizen suffrage would unlawfully dilute the value of citizen votes. ${ }^{176}$ But the Supreme Court has nowhere adopted one citizen-one vote as the constitutional standard, and it is hard to argue that it has done so implicitly.

In Reynolds v. Sims, ${ }^{177}$ the Supreme Court found that the Fourteenth Amendment's Equal Protection Clause "guarantees the opportunity for equal participation by all voters in the election of state legislators, $" 178$ and struck down an Alabama reapportionment scheme which included radical disparities in the population of various state legislative districts. ${ }^{179}$ In Wesberry $v$. Sanders, ${ }^{180}$

174 Congress promoted alien suffrage with the Northwest Ordinance of 1787 . See Act of Aug. 7,1789 , ch. 8,1 Stat. 50 . It also authorized aliens to vote in state constitutional conventions in Ohio, Indiana, Michigan, and Illinois. See ORDINANCE OF 1787: THE NORTHWEST TERRITORIAL GOVERNMENT, art. V; see also supra notes $72-$ 81 and accompanying text (discussing the adoption of an alien suffrage provision in Illinois and public policies supporting alien suffrage). Moreover, Congress admitted several states into the union whose constitutions explicitly provided for alien suffrage including Vermont, Virginia, Michigan, and Illinois. See VT. CoNST. of 1767, $\S$ XXXVIII; VA. CONST. of 1776; MICH. CONST. of 1835, art. II, $\S 1$; ILL. CoNST. of 1818, art. II, § 27; see also Spragins v. Houghton, 3 Ill. (2 Scam.) 377 (1840) (pointing out that Congress approved the republicanism of alien suffrage).

"It is here to be remembered, that the constitution of the state of Illinois was required, by the act of congress of the 18th of April, 1818, to be republican. ... By the resolution of the congress of the United States, of the $3 \mathrm{~d}$ December, 1818, it is expressly declared, that the constitution and state government so formed is republican ...."

Id. at 393.

175390 U.S. 474 (1968).

176 See id. at 475-76. The Supreme Court has held that state statutes "which may dilute the effectiveness of some citizens' votes, receive close scrutiny from this Court." Kramer v. Union Free Sch. Dist., 395 U.S. 621, 626 (1969) (citing Reynolds v. Sims, 377 U.S. 533, 562 (1964)). In Kramer, the court held that a New York Education Law, which limited the franchise in school district elections to those who had a primary interest in school affairs, violated the Equal Protection Clause because it did not accomplish its purpose with sufficient precision and was not necessary to promote a compelling state interest. See id. at 632.

177377 U.S. 533 (1967).

178 See id. at 566 (emphasis added).

179 Id. at 561-77.

180376 U.S. 1 (1964). 
where the Court invalidated on Article I grounds a lopsided districting scheme for U.S. Congressional districts in Georgia, ${ }^{181}$ the Court found that "the command of Art. I, § 2, that Representatives be chosen 'by the people of the several States' means that as nearly as is practicable one man's vote in a congressional election is to be worth as much as another's." 182 It is meaningful that in this formulation and others, the Wesberry Court employs not the language of "citizens" but of persons. ${ }^{183}$ This is more than a semantic point, because the rationale for the Court's decision was that "those who framed the Constitution meant that, no matter what the mechanics of an election, whether statewide or by districts, it was population which was to be the basis for the House of Representatives." 184 Population in the Constitution meant not the number of U.S. citizens living in the states, but "the whole Number of free Persons, including those bound to Service for a Term of Years, and excluding Indians not taxed, three fifths of all other Persons." 185

By this definition, aliens, who were voting in many places at the time, were to be included in the "population" and counted in the census. Today, aliens are still counted in the decennial census along with citizens and are thus factored numerically into congressional reapportionment. ${ }^{186}$ In another case elaborating the meaning of Reynolds, the Supreme Court denied that the Equal Protection Clause either requires or forbids the inclusion of aliens in the state legislative apportionment base, stating that the "decision to include or exclude [aliens, transients, short-term or temporary residents, or

181 See id. at 7-8.

182 Id. (quoting THE U.S. CONSTTTUTION) (emphasis added) (footnote omitted).

183 See id. at 7 ("If the Federal Constitution intends that when qualified voters elect members of Congress each vote be given as much weight as any other vote, then this statute cannot stand." (emphasis added)).

${ }^{184}$ Id. at 8-9 (emphasis added). The Court further found that

[t]he debates at the Convention make at least one fact abundantly clear: that when the delegates agreed that the House should represent 'people' they intended that in allocating Congressmen, the number assigned to each State should be determined solely by the number of the State's inhabitants. The Constitution embodied Edmund Randolph's proposal for a periodic census to ensure 'fair representation of the people,' an idea endorsed by Mason as assuring that 'numbers of inhabitants' should always be the measure of representation in the House of Representatives.

Id. at 13-14 (emphasis added) (footnote omitted).

185 U.S. CONST. art. 1, § 2, cl. 3 (this infamous provision was amended by Section 2 of the Fourteenth Amendment in 1868).

${ }^{186}$ See U.S. Census 1990. See generally Hyman Alterman, Counting People: THE CENSUS IN HISTORY (1969). 
persons denied the vote for conviction of crime] involves choices ... with which we have been shown no constitutionally founded reason to interfere. ${ }^{n 187}$

\section{B. The Suffrage Amendments}

A more subtle question is whether noncitizen voting offends the various suffrage amendments (the Fifteenth, Nineteenth, Twentyfourth and Twenty-sixth) which make explicit mention of "citizens." The Fifteenth Amendment provides: "The right of citizens of the United States to vote shall not be denied or abridged by the United States or by any State on account of race, color, or previous condition of servitude." ${ }^{188}$ If such language is not designed to exclude aliens from voting, perhaps it discloses a general understanding that voting is for citizens only. But this reading is badly strained: the language specifies only that states may not exclude any citizen from the franchise on the basis of race, not that the states may not include noncitizens in the franchise. Perhaps this is why the Court in Minor v. Happersett, ${ }^{189}$ sitting only four years after approval of the Fifteenth Amendment, did not interpret the appearance of the word "citizens" to invalidate the common and readily visible practice of noncitizen voting in the states. ${ }^{190}$

Beyond its plain language, the Fifteenth Amendment's legislative history shows that Congress clearly contemplated that noncitizen suffrage would survive the amendment's adoption. Such a definitive record exists thanks to Massachusetts Senator Charles Sumner, who in 1869 offered an amendment that would have extended the Fifteenth Amendment's reach to ban racial discrimination in voting not only against citizens but against noncitizens as well. ${ }^{191}$ The

${ }^{187}$ Burns v. Richardson, 384 U.S. 73, 92 (1966) (upholding Hawaii's use of registered voters as a legislative apportionment base, where such base led to distribution of legislators not substantially different from what would have resulted from the use of a population base).

${ }^{188}$ U.S. CONST. amend. XV, $\$ 1$ (emphasis added). In 1868 , two years before ratification of the Fifteenth Amendment, the addition of the Fourteenth Amendment marked the first appearance of the word "citizens" in the Constitution.

18988 U.S. (21 Wall.) 162 (1874).

190 See id. at 177.

191 Sumner's substitute language read: "The right to vote and hold office shall not be denied or abridged by the United States, nor by any State, on account of race, color or previous condition of servitude." CONG. GLOBE, 40th Cong., 3d Sess. 1030 (1869).

True to form, the brilliant and clever Sumner disingenuously disclaimed that his intention was to prevent racial discrimination in the enfranchisement of noncitizens, 
proposal provoked a vitriolic response from several Senators, mostly representing Western states, who opposed forcing alien suffrage states to share the vote with the swelling population of Chinese immigrants. ${ }^{192}$ These Senators argued that Sumner's amendment would deprive states of their power to extend the vote exclusively to aliens from Europe, forcing them to choose between enfranchising all aliens or none at all. Illinois Senator Lyman Trumbull rose quickly after Sumner introduced his amendment:

If you strike out the words "citizens of the United States" you extend this amendment. Now, in some of the states citizenship is not a requisite to suffrage; persons who are not citizens vote in some of the States of the Union. There would be nothing in this amendment, as the committee have [sic] reported it, to prevent those States discriminating against persons who are not citizens on account of race or color; but if the amendment proposed by the

arguing that the purpose of his amendment was only to clarify and shorten the language of the Fifteenth Amendment.

I am simplifying it now: I am reducing it to its minimum. The right to vote shall not be abridged on account of race or color; that is the proposition we want to establish. There is no occasion to burden it by the words "of citizens of the United States;" they are absolute surplusage there, and they burden the sentence. It is not a matter of any great consequence, however.

Id.

Unfortunately for Sumner, alert Senators from the West Coast, imbued with an extraordinary and unabashed anti-Chinese animus, detected the true meaning and effect of Sumner's amendment and unleashed a series of diatribes about the impact of enfranchising noncitizen Chinese and making them citizens. Indiana Senator Oliver Morton stated that:

[The Chinese] are now treated most brutally, as I am advised, in California and everywhere upon the Pacific coast. Their personal and civil rights are not regarded. They have submitted to this up to the present time; but as their numbers increase they may soon come to outnumber the white people upon that coast. It is not impossible that in the next ten or twenty years they may outnumber all other populations upon that coast; and then they will come to understand their power, and then the cruelties and brutalities that they now suffer and have suffered from the time they first went there may drive them to seize the political power into their hands. The fact that they made no such attempt up to this time does not prove that they may not yet do it."

Id. at 1034.

Sumner finally ended up addressing the merits of the racial issue, arguing that: "As I have read the Declaration of Independence, it says 'all men are created equal.' It does not say, 'all white men." Id. at 1035. But after finding himself alone in the debate, Sumner read the political writing on the wall and withdrew his amendment. See id.

192 See id. at $1030-40$ (statements of Senators Conness, Williams, Corbett, and Trumbull). 
Senator from Massachusetts is adopted the State of Michigan and the State of Indiana, which formerly, and I believe now, allowed persons to vote without naturalization, could not discriminate against unnaturalized persons on account of race or color; but if the committee's amendment is adopted they could so discriminate. So that striking out these words enlarges the scope of the proposition and takes from the State of Indiana, by way of illustration, the power of discrimination among unnaturalized persons on account of race or color. ... Citizenship and the right of suffrage were never synonymous terms; they do not necessarily go together at all. But if this amendment of the Senator from Massachusetts is adopted it will not be in the power of Indiana to discriminate against persons who are not citizens on account of race or color. ${ }^{193}$

Other Senators also made it clear that they opposed Sumner's amendment because they wanted to preserve the right of states to enfranchise white aliens while excluding the Chinese. ${ }^{194}$

Thus, the inclusion of the word "citizens" in the Fifteenth Amendment clearly does not work, and was not intended, to prevent noncitizen suffrage in the states. Rather, if the unabashed and highly specific intentions of Senator Sumner's adversaries are to be followed, the presence of the word "citizens" functions only to permit the states, in awarding the franchise, to discriminate between groups of noncitizens on the basis of race and color. Of course, it would be comforting to conclude that other Constitutional principles are available today to invalidate a law granting the vote to aliens of only one race, but it is not clear whether such principles have the momentum to overcome a legislative history so definitive in the eyes of a Supreme Court fixed on "original intent." 195 The

193 Id. at 1030.

194 See id. at 1033. Indiana Senator Oliver P. Morton stated:

Mr. President, there can be no mistake about one thing: that if the words "citizens of the United States" be stricken out, as suggested by the Senator from Massachusetts, the effect is to take away from any State the right to discriminate on account of race, color, or previous condition of slavery in the case of the Chinese, and that a Chinaman will be made eligible to office and will have the right to vote.

Id.

195 The Fourteenth Amendment's Equal Protection Clause, commanding that no state "deny to any person within its jurisdiction the equal protection of the laws," U.S. CONST. amend. XIV, $\S 1$ (emphasis added), is obviously the strongest candidate for such service in the unlikely event that a state were to pass such a law. It is clear that "an alien is entitled to the shelter of the Equal Protection Clause." Sugarman v. Dougall, 413 U.S. 634, 641 (1973) (striking down a New York law reserving 
important point is that no statement by any Senator at that time evinces any intention of foreclosing the option of alien suffrage to the states. The reappearance of the word "citizens" in the Nineteenth, Twenty-fourth and Twenty-sixth Amendments does nothing to alter the viability of this conclusion. ${ }^{196}$ It could be argued that, by closing the gap between citizenship and suffrage, the later suffrage amendments-the Nineteenth, Twenty-fourth and Twentysixth-implicitly confined the right of voting to citizens. ${ }^{197}$ But this argument collapses under the weight of three decisive problems. First, nothing in the legislative history of those amendments reflects an intention to revoke the states' power to grant alien suffrage. ${ }^{198}$ Second, from the standpoint of federalism, it is

permanent civil service positions to U.S. citizens). It can be argued that since the Equal Protection clause forbids racial discrimination, and since aliens constitute a suspect class within the meaning of the clause, a state actor could not extend the franchise to some groups of aliens but withhold it from others on the basis of race. See Strauder v. West Virginia, 100 U.S. 303 (1879) (striking down on equal protection grounds a West Virginia statute that denied to citizens the right to be jurors based solely upon their color).

This argument could encounter opposition on the current Supreme Court. After all, the legislative history surrounding passage of the Fifteenth Amendment can be read to furnish far more specific authority as to the framers' "original intent" regarding the voting rights of aliens. Given that the Supreme Court has never held that aliens have a Constitutional right to vote and that the more recent trend is to cut back on equal protection coverage for aliens, see Cabell v. Chavez-Salido, 454 U.S. 432, 436-47 (1982) (upholding a California law preventing aliens from becoming peace officers); Foley v. Connelie, 435 U.S. 291, 294-300 (1978) (sustaining against equal protection attack a New York law requiring police officers to be U.S. citizens), it is at best uncertain whether this Court would strike down a racially discriminatory alien suffrage law. On the other hand, antidiscrimination principles may now be so embedded in the fabric of the Constitution that such a judgment may be unduly pessimistic.

${ }^{196}$ These three amendments track the language of the Fifteenth Amendment in stating that the "right of citizens" to vote shall not be "denied or abridged" on account of sex, failure to pay a poll tax, or age (so long as the citizen is eighteen), respectively. There is nothing in the legislative histories of the passage of these three amendments that reveals an intention to remove the state power to grant alien suffrage. The prohibitions contained in these amendments are directed only at discriminatory state action towards specific groups of citizens and accomplish no change in the state's general power to define the electorate.

197 The Supreme Court of Alaska made precisely this argument in the course of finding that the state constitutional provision barring aliens from voting in Alaska did not violate equal protection. See Park v. State, 528 P.2d 785, 787 (1974) ("Because all of these voting rights [contained in the Fifteenth, Nineteenth, Twenty-fourth, and Twenty-sixth Amendments of the United States Constitution] are applied expressly only to citizens, the necessary implication is that such rights are not available to aliens."). This argument is both a logical fallacy and a misreading of constitutional history.

198 There is no evidence, for example, that the Nineteenth Amendment was ever 
tenuous to suggest that the Constitution has categorically prohibited a historically common and accepted state practice indirectly and by way of implication. This is especially so in the voting area, where the judiciary has traditionally deferred to the plenary power of the states, interfering only to expand-not contract-the circle of democratic inclusion. ${ }^{199}$ Finally, citizenship and suffrage continue to be distinct legal categories: not all citizens get to vote, and not all voters are citizens. Several classes of citizens, such as ex-felons in many states, and children in all of them, are still disenfranchised. ${ }^{200}$ Conversely, noncitizens are still permitted to vote in certain local elections, such as school board elections in Chicago and New York and municipal elections in a number of Maryland

interpreted at the time of passage to abolish the power of states to enfranchise noncitizens. Indeed, the amendment enfranchising women was ratified by three states engaging in the practice (Arkansas, Indiana, and Texas) and none saw it as impairing the policy of alien suffrage. See 66 CoNG. REC. 635 (1920). Furthermore, the Supreme Court has explicitly linked the role of the Nineteenth Amendment to that of the Fifteenth Amendment. See Leser v. Garnett, 258 U.S. 130, 136 (1972) (" The Nineteenth Amendment] is in character and phraseology precisely similar to the Fifteenth.").

${ }^{199}$ See Oregon v. Mitchell, 400 U.S. 112, 125 (1970) (stating that "[n]o function is more essential to the separate and independent existence of the States and their governments than the power to determine within the limits of the Constitution the qualifications of their own voters for state, county, and municipal offices"). It is wellaccepted that "the Framers of the Constitution intended the States to keep for themselves, as provided in the Tenth Amendment, the power to regulate elections." Id. at 124-25 (footnote omitted). The Constitutional inroads made against the states' power over voting all reflect the conception of an expanding franchise. See U.S. CONST. amend. XIV, XV, XIX, XXIV, XXVI. Furthermore, the Court has usually intervened only to defend voting rights. See Dunn v. Blumstein, 405 U.S. 330 (1972) (striking down a one-year residency requirement); Harper v. Virginia State Bd. of Elections, 383 U.S. 663 (1966) (striking down poll tax). Where courts have decided against voting rights, it is only in the course of acquiescing to state restrictions on the franchise. See Holt Civic Club v. Tuscaloosa, 439 U.S. 60 (1978) (upholding a state statute which made residents of a suburban community subject to certain city regulations, but not allowing them to participate in city elections); Lassiter v. Northampton County Bd. of Elections, 360 U.S. 45 (1959) (upholding a literacy requirement for voting). It would be extraordinary for a court to strike down a state law extending the vote to state residents.

200 See Note, The Disenfranchisement of Ex-Felons: Citizenship, Criminality, and "The Purity of the Ballot Box," 102 HARv. L. REv. 1300 (1989); Vita Wallace, Give the Children the Vole, THE NATION, Oct. 14, 1991, at 439.

It may be objected that children and ex-felons, both groups of citizens, are only permissibly excluded from the franchise because of the implications of Section 2 of the Fourteenth Amendment. But aliens stand on the same footing as they do. Without this language in Section 2, the argument that aliens have a constitutional right to vote would have additional, if not decisive, force. 
localities. ${ }^{201}$ Nothing in the suffrage amendments requires states to confine voting to U.S. citizens.

\section{The Naturalization Clause}

Article I, Section 8 confers on Congress the power to "establish an uniform Rule of Naturalization .... ${ }^{202}$ The question may arise whether state or local enfranchisement of noncitizens is inconsistent with this power and therefore invalid under the Constitution's Supremacy Clause. ${ }^{203}$ This question does not, in fact, pose a serious problem because alien voting in no way interferes with congressional control over immigration and naturalization. Of course, any local law that purports to modify the terms of a resident's immigration status is presumptively in violation of the Supremacy Clause and preempted by federal immigration law. ${ }^{204}$ But noncitizen voting does not subtract from the obligations imposed on aliens by immigration law or otherwise frustrate the purposes of such law. The simple right to vote in local elections, or even state and federal elections, neither confers U.S. citizenship for federal purposes nor immunizes aliens against the operation of any provision of immigration or naturalization law. ${ }^{205} \mathrm{~A}$ resident alien who today has the right to vote in a B7.

201 See Jamin B. Raskin, Votes for Al, Citizens or Not, L.A. TIMES, Nov. 13, 1991, at

202 U.S. CONST. art. I, $\$ 8, \mathrm{cl}$. 4. The Congressional power over immigration and naturalization has been construed broadly. See LAWRENCE TRIBE, AMERICAN CONSTITUTIONAL LAW \$ 5-16 (1988) ("Sweeping as are Congress' war-related powers, the Court has emphasized time and again that "over no conceivable subject is the legislative power of Congress more complete than it is over" the admission of aliens.") (quoting Fiallo v. Bell, 430 U.S. 787, 792 (1977), quoting Oceanic Navigation Co. v. Stranahan, 214 U.S. 320, 339 (1909))). The deference shown Congress in this field, however, does not weaken the argument here because the institution of noncitizen suffrage in no way interferes with the exercise of that power.

203 U.S. CoNST. art. VI, cl. 2.

204 See Davis v. Elmira Savings Bank, 161 U.S. 275, 283 (1896). It has long been recognized that any state or local effort to interfere with federal policies and agencies "is absolutely void, wherever such attempted exercise of authority expressly conflicts with the laws of the United States, and either frustrates the purpose of the national legislation or impairs the efficiency of these agencies of the federal government to discharge the duties for the performance of which they were created." Id. The test is whether a law in question "stands as an obstacle to the accomplishment and execution of the full purposes and objectives of Congress." Hines v. Davidowitz, 312 U.S. 52, 67 (1941). For example, permitting all residents of Cleveland to vote in local elections, regardless of citizenship, would not be preempted, but providing that all residents of Cleveland, including aliens, are citizens of the United States, would be.

205 The voting noncitizen does not become a citizen for the purposes of running 
Chicago school board election could be deported tomorrow by the Immigration and Naturalization Service for various statutory reasons, including marriage fraud, ${ }^{206}$ smuggling, ${ }^{207}$ terrorist activities, ${ }^{208}$ or criminal conviction for most narcotics ${ }^{209}$ and firearm offenses. ${ }^{210}$ Both aliens and citizens can break the law, and the right of aliens to vote no more impairs the efficiency of the Immigration and Naturalization Service in enforcing immigration law than the right of citizens to vote impairs the efficiency of the Justice Department in enforcing criminal law. ${ }^{211}$ In sum, the United States Constitution places no obstacles in the path of states and localities willing to enfranchise noncitizens. ${ }^{212}$

\section{Is Alien Suffrage Constitutionally Mandatory?}

The obverse of the argument that the Constitution forbids alien voting is that the Constitution requires it. Fifteen years ago, Gerald Rosberg presented a good argument for this proposition: that equal protection should be read to guarantee the right of resident aliens in the states to vote at all levels of government. ${ }^{213}$ Although Rosberg's thesis offers important insights into the value of alien suffrage, it runs against the language of the Fourteenth Amendment and defies the logic of suffrage expansion in the United States. For even if we follow the doctrinal somersaults required to arrive at

for the House of Representative after seven years or for the Senate after nine years. See U.S. CoNST. art. I, § 3. Nor does she become a citizen for the purposes of gaining immunity from state laws which may legitimately discriminate against noncitizens. See supra note 136.

${ }^{206}$ See 8 U.S.C. $\$ 1251$ (a)(1)(G) (1988 \& Supp. III 1991).

207 See id. § 1251(a)(1)(E).

208 See id. \$ 1251(a)(4)(B).

209 See id. \$ $1251(\mathrm{a})(2)(\mathrm{B})$.

210 See 8 U.S.C.A. \$ 1251(a)(2)(C) (West Supp. 1992). Other classes of deportable aliens include those who were excludable by law at the time of entry, those who entered without inspection, and those who are engaged in espionage, sabotage, or any efforts to overthrow the government of the United States. See 8 U.S.C. \$ 1251 (1988 \& Supp. III).

211 See Davis v. Elmira Savings Bank, 161 U.S. 275, 283 (1896).

212 But see Neuman, supra note 13, at 324 ("It is probably true, however, that modern constitutional law would uphold an explicit congressional prohibition on alien voting."). This judgment is probably accurate given the great latitude the Supreme Court has allowed Congress in defining its naturalization power. But the historical role played by alien suffrage in American local self-government and the traditional power of states and localities to define their own electorates could equally yield the conclusion that an attempted congressional prohibition on noncitizen voting would infringe on the Tenth Amendment interests of the states or the people.

213 See generally Rosberg, supra note 13. 
Rosberg's position, his argument is not wholly persuasive as a description, historical or normative, of how the franchise expands in the American polity. None of the principal excluded national groups who gained access to the ballot in American history did so by way of judicial action through the Equal Protection Clause. Rather, they fought their way in through political agitation. This history encloses an important democratic logic: it is the standing citizenry, after hearing and debating appeals from the voteless, that must extend rights of political membership to disenfranchised outsiders seeking entry and equality.

Rosberg acknowledged that "the Supreme Court's inclination on this issue is not at all in doubt." ${ }^{214}$ Shortly before he wrote his article in 1977, the Supreme Court had dismissed an appeal from the Colorado Supreme Court's decision in Skafte v. Rorex, ${ }^{215}$ which found that the Constitution did not require Colorado to grant noncitizens voting rights in local elections. In Skafte, a permanent resident alien claimed that the Colorado statutes that denied him the right to vote in school board elections violated not only the Equal Protection Clause but also the Due Process and the Supremacy Clauses. ${ }^{216}$ The Colorado Supreme Court rejected each claim, finding that on the equal protection argument the United States Supreme Court "has consistently used language suggesting that citizenship with respect to the franchise is not a suspect classification." ${ }^{217}$ Applying the mere rationality test, the Colorado court decided, in a conclusory and somewhat overheated passage, that the "state has a rational interest in limiting participation in government to those persons within the political community. Aliens are not a part of the political community." ${ }^{218}$ The court went on to reject the argument that citizenship is a permissible suffrage restriction in general elections but not school board elections, finding sufficient indications in prior U.S. Supreme Court decisions to conclude that "school elections are elections involving participation by the political community." ${ }^{219}$ In denying the appeal in Skafte, the

214 Id. at 1100 .

${ }^{215} 553$ P.2d 830 (Colo. 1976), appeal dismissed, 430 U.S. 961 (1977).

216 See Skafte, 553 P.2d at 830.

${ }^{217}$ Id. at 832. The Colorado court relied on Supreme Court precedent in rejecting the equal protection, due process, and supremacy arguments. See id. at 833 35.

${ }^{218} \mathrm{Id}$. at 832 . The Colorado court would have been on firmer ground if it had found that aliens are not a necessary part of the political community.

$219 \mathrm{Id}$. at 833 . The Court also noted that "voting in school elections involves 
Supreme Court simply noted that the case lacked a substantial federal question and summarily invoked the authority of Sugarman v. Dougall ${ }^{20}$ and Kramer v. Union Free School District. ${ }^{221}$ In Sugarman, the Court remarked: "This Court has never held that aliens have a constitutional right to vote or to hold high public office under the Equal Protection Clause. Indeed, implicit in many of this Court's voting rights decisions is the notion that citizenship is a permissible criterion for limiting such rights. ${ }^{222}$ In Kramer, the Court struck down a New York law limiting the franchise in certain school board elections to parents of children in school and those owning or leasing local taxable property. ${ }^{223}$ The Court there noted that even the plaintiff, an adult bachelor living at home with his parents, did not contest "that the States have the power to impose reasonable citizenship, age, and residency requirements on the availability of the ballot." 224

Rosberg found irony in the Court's invocation of Sugarman and Kramer to reject the argument that the Constitution required alien suffrage. ${ }^{225}$ Sugarman had determined that aliens were a suspect class for equal protection purposes. ${ }^{226}$ Kramer found that statutes limiting the franchise give rise to strict or "exacting" judicial scrutiny because the right to vote is fundamental and "preservative of other basic civil and political rights. ${ }^{n 227}$ If any two cases could produce an argument that alien voting was constitutionally compelled, Rosberg imagined, it would be the combination of Sugarman and Kramer. But the Supreme Court mobilized these cases for the opposite purpose: to show that aliens were not a suspect class for voting purposes and that voting statutes that enforced citizenship qualifications transgressed no constitutional boundary. ${ }^{228}$

participation in the decision making process of the polity, a factor which indicates the "general' nature of such elections." Id. It was an easy step then for the court to find that the statutory classification depriving aliens of the right to vote was "properly tailored to the state's interest." Id.

${ }^{220} 413$ U.S. 634 (1973).

221395 U.S. 621 (1969).

222 Sugarman, 413 U.S. at $648-49$.

${ }^{223}$ See Kramer, 395 U.S. at $625,631-33$.

224 Id. at 625.

225 See Rosberg, supra note 13, at 1102 ("By citing the discussion of alien voting in Sugarman and Kramer, the Supreme Court evidently wanted to show that even at the time it was formulating these propositions it did not believe that they could be carried to the point of establishing a right to vote for aliens.").

226 See Sugarman, 413 U.S. at 641.

227 Kramer, 395 U.S. at 626, 628-29 (quoting Reynolds v. Sims, 377 U.S. 533, 562 (1964)).

${ }^{228}$ This was not the first time that the Court failed to take an opportunity to find 
Rosberg develops a powerful and syllogistic counter-argument. Voting, he correctly maintains, has never been construed as "a right or privilege of state or national citizenship" under the Privileges and Immunities Clause of Article $\mathrm{IV}$ or the Fourteenth Amendment. ${ }^{229}$ Indeed, the so-called "right to vote" does not exist but is simply a "convenient shorthand for the right to "participate in state elections on an equal basis with other qualified voters whenever the State has adopted an elective process." 230 But this "right to equal treatment, as the voting rights cases have clearly acknowledged, is derived from the [E]qual [P]rotection [C]lause, which declares that no state shall deny any person the equal protection of the laws. ${ }^{231}$ It is this language which has enabled the Court to strike down state laws that discriminate against persons on the basis of alienage. Thus, Rosberg concludes, "[i]f the right to equal treatment in the electoral process owes its origin to the [E]qual [P]rotection [C]lause, and it undeniably does, then whatever the dicta in earlier cases it must be persons and not just citizens who enjoy that right." ${ }^{232}$ If a state offers anyone within its borders the right to vote, it may not deny the vote to aliens unless its decision "can pass the rigorous test of strict scrutiny." 233 The rest of Rosberg's argument seeks to demonstrate that any asserted state interests in depriving aliens of the right to vote are not sufficiently compelling to sustain strict scrutiny under the Equal Protection Clause. ${ }^{234}$

alien suffrage a constitutional necessity. Most of the passages from Supreme Court opinions used to refute the idea that alien voting is forbidden by the Equal Protection Clause function equally well to refute the idea that alien voting is compulsory under the Equal Protection Clause.

${ }_{229}$ Rosberg, supra note 13 , at 1108.

${ }^{230}$ Id. (citing San Antonio Indep. Sch. Dist. v. Rodriguez, 411 U.S. 1, 35 n.78 (1973)).

${ }^{231}$ Id. at 1108-09. Even this approvingly relayed passage from Rodriguez, 411 U.S. at $35 \mathrm{n.78}$ (1973), however, pulls against the conscious direction of Rosberg's argument. Note that the Court affirms only the right to "participate in state elections on an equal basis with other qualified voters whenever the State has adopted an elective process." Id. (emphasis supplied). Of course, if aliens are not qualified voters, then the Equal Protection Clause does not secure their right to participate equally in the electoral process.

232 Rosberg, supra note 13 , at 1109.

${ }^{233} I d$.

${ }^{234}$ See id. at 1109-35. Rosberg contends that the following asserted state interests are constitutionally insufficient to uphold the disenfranchisement of aliens: that they lack a "sufficient stake" in governmental affairs; that they are likely to practice vote frand; that they vote as a bloc; that they lack the knowledge required to cast an intelligent vote; and that they are missing the required loyalty to the nation and its political institutions. See id. at 1115. Rosberg's probing discussion of these claims 
This cogent argument encounters one large doctrinal roadblock, recognized (if a bit brusquely) by Rosberg, ${ }^{235}$ in the Fourteenth Amendment itself. Section 2 includes little-noticed language clearly indicating constitutional permission for states to impose citizenship as a voting qualification. It states that:

Representatives shall be apportioned among the several States according to their respective numbers, counting the whole number of persons in each State, excluding Indians not taxed. But when the right to vote at any election for the choice of electors for President and Vice President of the United States, Representatives in Congress, the Executive and Judicial officers of a State, or the members of the Legislature thereof, is denied to any of the male inhabitants of such State, being twenty-one years of age, and citizens of the United States, or in any way abridged, except for participation in rebellion, or other crime, the basis of representation therein shall be reduced in the proportion which the number of such male citizens shall bear to the whole number of male citizens twenty-one years of age in such State. ${ }^{236}$

This provision, which operates to reduce a State's House representation in direct proportion to the number of its disenfranchised adult male citizens, white or black, marked a compromise between radical Republicans in Congress who wanted to guarantee all black citizens the right to vote and conservative Democrats who sought to preserve total state control over the franchise. ${ }^{237}$ On the terms of the compromise, a state could employ a literacy test to keep blacks from voting, but would then face the prospect of not retaining its full representation in Congress. 238 "In the historical context, no one could have understood this language as anything other than an abandonment of the principle of Negro suffrage ...."239 Many radical Republicans thus attacked the Fourteenth Amendment "[b]ecause it implicitly acknowledged the right of states to limit voting because of race, Wendell Phillips denounced the amendment as a 'fatal and total surrender."'240

generates excellent policy arguments for alien suffrage even if, as contended here, the underlying Fourteenth Amendment analysis to which they are attached is weak.

235 See Rosberg, supra note 13, at 1102-04.

236 U.S. CONST. amend. XIV, § 2.

237 See FONER, supra note 11, at 252-53.

238 See id at 253.

239. Oregon v. Mitchell, 400 U.S. 112, 162 (Harlan, J., concurring in part and dissenting in part).

240 FONER, supra note 11, at 255 (quoting Stevens Papers, Communication of Wendell Phillips to Thaddeus Stevens (Apr. 30, 1866)). Others thought that this 
Justice Harlan later wrote that the "only sensible explanation of $\$ 2 \ldots$ is that the racial voter qualifications it was designed to penalize were understood to be permitted by $\S 1$ of the Fourteenth Amendment." 241 But the language of the Fourteenth Amendment's second section reveals not only a willingness to permit, for a price, the disenfranchisement of blacks; there is also the inescapable implication that women, noncitizens, criminals, and those under twenty-one years of age do not form a necessary part of a core voting polity. For, while the disenfranchisement of AfricanAmericans at least triggered an automatic constitutional reduction in the national political power of the white male political class, the disenfranchisement of women, aliens, and criminals had no such effect. These categories of exclusion were thus considered not only within the actual power of the states, but within the range of unpunished and normatively acceptable options. Indeed, for this reason, Susan B. Anthony, Elizabeth Cady Stanton, and other leaders of the women's suffrage movement "felt betrayed, because the second clause for the first time introduced the word 'male' into the Constitution." 242

Later cases confirmed the implication in Section 2 of the Fourteenth Amendment that Section 1 did not prohibit discrimination in voting against certain enumerated groups. The Court's 1970 decision in Oregon $v$. Mitchell ${ }^{243}$ is especially instructive in this regard. The Court found there that it was beyond the power of

indirect method of encouraging states to enfranchise blacks was the best that could be hoped for until another amendment could be passed to deal with black voting rights directly. See id. at 261. "Henry M. Turner, the black minister and political organizer who had been sent to Washington to lobby for black rights by Georgia's statewide black convention, reported home: 'several Congressmen tell me, "the negro must vote," but the issue must be avoided now so as "to keep up a two thirds power in Congress." Id. (quoting John E. Bryant Papers, Communication of Henry M. Turner to John E. Bryant (Apr. 13, 1866)).

${ }^{241}$ Mitchell, 400 U.S. at 169-70. Harlan canvassed the legislative history of the Fourteenth Amendment contained in the Journal of the Joint Committee on Reconstruction. He concluded that it yielded with "startling clarity" first, that "the Committee regularly rejected explicitly enfranchising proposals in favor of plans which would postpone enfranchisement, leave it to congressional discretion, or abandon it altogether," and second, that "the abandonment of Negro suffrage as a goal exactly corresponded with the adoption of provisions to reduce representation for discriminatory restrictions on the ballot." Id. at 170-71.

${ }^{242}$ FONER, supra note 11, at 255. Foner goes on to state, incorrectly: "Alone among suffrage restrictions, those founded on sex would not reduce a state's representation." Id. Alienage, age, and criminal status also were deemed categories upon which states could premise exclusion with impunity.

243400 U.S. $112(1970)$. 
Congress to establish, as it had attempted to do in the 1970 Amendment of the Voting Rights Act, the right of eighteen-yearolds to vote in state and local elections. ${ }^{244}$ As Justice Black stated: "No function is more essential to the separate and independent existence of the States and their governments than the power to determine within the limits of the Constitution the qualifications of their own voters for state, county, and municipal offices ...."245 On the other hand, a majority in Mitchell also found that Congress did possess the constitutional power-under Article I, Section 2 and the Necessary and Proper Clause, according to Justice Black, ${ }^{246}$ or Section 5 of the Fourteenth Amendment, according to Justice Douglas ${ }^{247}$-to grant eighteen-year-olds the right to vote in national elections.

It is important to recall that eighteen-year-olds, like aliens, are within the class of persons which Section 2 of the Fourteenth Amendment implicitly consigned to their fate in the political processes of the states. Thus, Rosberg's argument that aliens have a constitutional right to vote in state elections even without congressional legislation loses force when it is recognized that eighteen-year-olds were deemed by the Supreme Court not to have such a right even with congressional legislation.

The message contained in Mitchell was sharpened and elaborated in the Supreme Court's 1974 decision in Richardson v. Ramirez. ${ }^{248}$ In Ramirez, the Court reversed a California Supreme Court judgment holding that California's disenfranchisement of convicted felons violated equal protection. ${ }^{249}$ Crucial to the Court's decision was its interpretation of Section 2 of the Fourteenth Amendment, which reduces the popular basis for representation when a state denies the right to vote "to any of the male inhabitants of such State, being twenty-one years of age, and citizens of the United States ... except for participation in rebellion, or other crime." 250 Focusing on the meaning of the italicized section, Justice Rehnquist determined that "the exclusion of felons from the vote has an affirmative sanction in $\S 2$ of the Fourteenth Amendment, [and] . . .

244 See Oregon, 400 U.S. at 118.

245 Id. at 125 (Opinion of Black., J.).

246 See id. at $119-31$.

247 See id. at 141-44 (Douglas, J., concurring in part and dissenting in part).

248418 U.S. 24 (1974).

249 See id. at 56.

250 Oregon v. Mitchell, 400 U.S. 112, $161 \mathrm{n} .12$ (emphasis added) (quoting U.S. ConsT. amend. XIV, § 2). 
that $\S 1$, in dealing with voting rights as it does, could not have been meant to bar outright a form of disenfranchisement which was expressly exempted from the less drastic sanction of reduced representation which $\S 2$ imposed for other forms of disenfranchisement." 251

Rosberg readily conceded that, as construed in the Ramirez case, "section 2 of the [F]ourteenth [A]mendment disposes of the claim that a denial of the vote to aliens is unconstitutional under section 1."252 This is a necessary conclusion given that "[s]ection 2 treats aliens and felons precisely alike-a state that denies the vote to aliens is just as free from any sanction under section 2 as a state that denies the vote to felons." 253 But Rosberg cast doubt on the durability of Ramirez and then stated that, "even if section 2 is dispositive, it is not a very satisfying way to dispose of the case because it resolves the equal protection arguments by making it unnecessary to consider them on the merits. ${ }^{254}$ Throwing doctrine to the winds, he proceeded to his strict scrutiny equal protection analysis.

Rosberg is, of course, free to dispute the merits of the Ramirez decision and to argue, quite elegantly, that it "goes well beyond anything required by the language, history, or purpose of the [F]ourteenth [A]mendment." ${ }^{255}$ But even if Section 2 did not implicitly condone different levels of suffrage discrimination in the states, important reasons remain to be skeptical of the claim that Section 1 of the Fourteenth Amendment should be construed to secure the right of noncitizens to vote. The pathway to political membership taken by disenfranchised groups in the American community has been constitutional politics and amendment, not constitutional litigation and interpretation. ${ }^{256}$ The property qualification was dropped, not after court decisions, but after democratic agitation in the states for statutory and constitutional changes. ${ }^{257}$ The Fourteenth Amendment did not alter this dynamic: with the general terms of Section 1 and negative implica-

251 Ramirez, 418 U.S. at 54-55.

252 Rosberg, supra note 13, at 1103.

253 Id. at 1103-04.

254 Id. at 1104 .

255 Id.

${ }^{256}$ See generally SHKLAR, supra note 5, at 25-62 (discussing the political struggle of groups formerly disenfranchised).

${ }^{257}$ See generally WILLIAMSON, supra note 7 (examining the circumstances in which the freehold qualification was eliminated in the various states). 
tions of Section 2, it completely failed to confront the problem of black disenfranchisement, much less the disenfranchisement of women. Much later, the Fourteenth Amendment came to play a role in advancing principles of equal protection among eligible and existing registered voters, ${ }^{258}$ but African-Americans were only liberated from their widespread disenfranchisement and subjugation under Dred Scott ${ }^{259}$ by way of the enactment of the Fifteenth Amendment, ${ }^{260}$ passed two years after the Fourteenth Amendment and the Voting Rights Act of 1965. Similarly, women only escaped their Court-approved disenfranchisement through passage of the Nineteenth Amendment in 1920. ${ }^{261}$ And eighteen-year-olds gained the complete right to vote in 1971 with ratification of the Twenty-Sixth Amendment. ${ }^{262}$ This constitutional amendment became necessary after a majority of the Supreme Court, in Oregon v. Mitchell, ${ }^{263}$ found that Congress did not have the power, under Section $\mathbf{5}$ of the Fourteenth Amendment or any other constitutional provision, to invade the political domain of the states by lowering the voting age in state and local elections to eighteen.

There may be grounds to criticize judicial reluctance to declare new voting rights for excluded groups, but it is not clear that judicial, as opposed to political, enlargement of the franchise is to be preferred. The matter of who votes is the central question in a community's process of political self-definition. It is, therefore, a constitutional question in the strictest sense of the word: it determines who constitutes the body politic. While it is often thought that constitutional questions belong exclusively to the courts, Paul Brest has rightly emphasized that "[c]onstitutional discourse and decision-making are the most fundamental prerogatives and responsibilities of citizens." ${ }^{264}$ It is clearly more demo-

${ }^{258}$ See, e.g., Kramer v. Union Free Sch. Dist., 395 U.S. 621, 630-33 (1969) (upholding the right of an otherwise eligible voter who does not own or otherwise lease taxable property or have children enrolled in public schools to vote in school district elections); Carrington v. Rash, 380 U.S. 89, 96 (1965) (establishing the right of a member of the armed services to vote where he is domiciled in the service even if he did not reside there prior to service); Reynolds v. Sims, 377 U.S. 533, 568 (1964) (establishing the principle of one person-one vote in state legislative elections).

25960 U.S. 393 (1856).

260 U.S. CONST. amend. XV.

261 U.S. CONST. amend. XIX.

262 U.S. CoNST. amend. XXVI.

263400 U.S. 112, 117-18 (1970).

264 Paul Brest, Further Beyond the Republican Revival: Toward Radical Republicanism, 97 YALE L.J. 1623, 1628 (1988) (emphasis omitted). 
cratic to permit citizens, rather than judges, to decide who may enter the constitutive political space of the society. Those currently voting have an obvious interest in defining the franchise: every prospective new voting member theoretically dilutes the voting power of each current member or enriches the meaning of the political community for all. Indeed, the definition of the electorate is closely linked to the character and destiny of the community. The very democratic logic which argues for alien suffrage-that the governed should be able to participate in decisionmaking over them-strongly suggests that it is the existing electorate which should determine the shape of the electorate to come. ${ }^{265}$ Furthermore, social contracts that are expanded by citizens themselves are surely made of more durable stuff than social contracts renegotiated by judicial power.

It could be objected that popular reluctance to share the vote with new groups requires judicial control over definition of the electorate. But this objection greatly underestimates not only the ability of disenfranchised groups to communicate their cause to voting members of society, but also the willingness of voters to listen. In both American and European history, citizens have regularly expanded the franchise when confronted with a compelling logic to do so. The propertied enfranchised the propertyless, whites enfranchised blacks, men enfranchised women, and so on. More to the point, the voteless fared much better appealing to the people and to the legislative, as opposed to the judicial, process. The Supreme Court gave us Dred Scott ${ }^{266}$ and Minor v. Happersett, ${ }^{267}$ but Congress and two-thirds of the states gave us the Fifteenth Amendment and women's suffrage. There is no reason to think that courts will glimpse the logic of extending the franchise earlier than the people themselves, who have a much greater understanding of the meaning of voting for people lacking other

265 Moral philosopher Michael Walzer has come to the same conclusion about the analogous question of who may fix immigration policies and define standards of national membership: "Initially, at least, the sphere of membership is given: the men and women who determine what membership means, and who shape the admissions policies of the political community, are simply the men and women who are already there." Michael Walzer, Spheres of Justice: A Defense of PluRalism AND EQUALITY 43 (1983). "It is important first to insist that the distribution of membership in American society, and in any ongoing society, is a matter of political decision." Id. at 40.

26660 U.S. 393 (1856).

26788 U.S. 162, 178 (1874) (upholding the provision of the Missouri state constitution which denied females the right to vote). 
kinds of social power and resources. While Rosberg makes an attractive argument that the Supreme Court veered away from a plausible destination for its equal protection holdings, ${ }^{268}$ he neglects the deep meaning of the American constitutional experience. Enlargement of the electorate has taken place by way of democratic amendment to the Constitution, ${ }^{269}$ not judicial reappraisal of the meaning of constitutional terms long present. Of course, this contention may be resisted in the alien suffrage context by those who assume that citizens would simply never extend the right to vote to noncitizens. But this assumption is not only wrong as a matter of history, but, as I shall now argue, unduly fatalistic as a matter of present political judgment.

\section{The Case in Democratic Theory for Noncitizen VOTING AT THE LOCAL LEVEL}

The argument for noncitizen voting in local government is founded on the essential democratic ideas that pervade American political and constitutional development. From the time of the Revolution these ideas were central to the development of alien suffrage, and they will form the principal rationale for any renewal of the practice. But these ideas are bolstered today by evolving norms of international human rights and "community democracy," norms which reflect profound changes in global economic structure and tremendous surges in international immigration. The present case for noncitizen voting thus draws on both classical American democratic principles and an emerging global ideology of local democracy.

\section{A. The Classical Democratic Argument}

The traditional democratic argument for suffrage rights, formulated in the language of liberalism and natural rights, has never lost its vitality. ${ }^{270}$ It is second nature to Americans, reducible to a few familiar maxims: government must rest on the consent

${ }^{268}$ See Rosberg, supra note 13, at 1109 (arguing that "[i]f the right to equal treatment in the electoral process owes its origin to the [E]qual [P]rotection [C]lause, ... it must be persons and not just citizens who enjoy that right").

269 See U.S. CoNST. amend. XIV, XV, XVI, XIX.

270 "No historically significant form of government or of citizenship is in principle incompatible with the exclusion of large groups of people, but natural-rights theory makes it very difficult to find good reasons for excluding anyone from full political membership in a modern republic." SHKLAR, supra note 5, at 37. 
of the governed, ${ }^{271}$ no taxation without representation, ${ }^{272}$ and good-enough-to-fight-good-enough-to-vote. ${ }^{273}$ Taken seriously, these principles would destroy the seemingly principled dividing line in the franchise which separates aliens from citizens.

Resident aliens are governed by our political institutions and are subject to all laws which apply to citizens (and many which do not); they must pay all taxes that citizens pay, ${ }^{274}$ they have fought as soldiers in every major American war, and have, in various categories, been subject to the military draft. ${ }^{275}$ Because aliens lack votes, the principal currency in which democratic politicians trade, they are made especially susceptible to official discrimination and hostility in the political system. As a French political scientist has written, 'immigrants' absence from the political arena makes this a biased market in which xenophoebic [sic] initiatives can earn votes without incurring the risk of losing other votes. ${ }^{276}$

The classical democratic arguments for local alien suffrage are captured beautifully in a concurrence by Justice Blackenridge in the 1809 Pennsylvania case of Stewart $v$. Foster, ${ }^{277}$ the first reported case on local noncitizen voting. In Stewart, an alien freeholder who had been living and paying taxes in Pittsburgh for the required oneyear period was denied the right to cast his vote by the election judges. ${ }^{278}$ Justice Blackenridge agreed with the court's judgment that Stewart had a legal right to vote because the legislature had

271 See THE DECLARATION OF INDEPENDENCE para. 2 (U.S. 1776) ("[T]o secure these rights, governments are instituted among Men, deriving their just powers from the consent of the governed.").

272 This was the cry of the American Revolutionaries. See generally BERNARD BAILYN, THE IDEOLOGICAL ORIGINS OF THE AMERICAN REVOLUTION 117, $209-21$ (1967) (arguing that the colonists experienced Parliament's illegal taxation as a "deliberate assault of power upon liberty" and explaining how they objected to the Stamp Act's transgression of the colonies' proper sphere of governance).

${ }^{273}$ See WILLIAMSON, supra note 7, at 133 (quoting an American verteran: "[W]e fought for the right of voting and we will now exercise it." (citation omitted)).

274 See 26 C.F.R. \$ 1.1-1(b) (1992) ("[A]ll citizens of the United States . . . and all resident alien individuals are liable to the income taxes imposed by the Code . . . "); see also Ambach v. Norwick, 441 U.S. 68, 81 n.14 (1979) ("As our cases have emphasized, resident aliens pay taxes [and] serve in the Armed Forces . . ..").

275 See infra note 315 and accompanying text.

276 Yann Moulier-Boutang, Resistance to the Political Representation of Alien Populations: The European Paradox, 19 INT'L MIGRATION REV. 485, 489 (1985) (footnote omitted); see also Johnson, supra note 12, at 279, 360 (pointing out that aliens seeking asylum are politically bulnerable).

2772 Binn. 110 (Pa. 1809).

278 See id. (stating that the issue is whether an alien is entitled to vote in a borough election) (emphasis added). 
intended to enfranchise aliens in Pittsburgh local elections. ${ }^{279}$ But Blackenridge pressed further, arguing that it would have been "wrong," according to constitutional, corporate or natural law principles, for the state to exclude aliens from these elections. ${ }^{280}$ His argument invoked two main lines of democratic principle:

The being an inhabitant, and the paying tax, are circumstances which give an interest in the borough. The being an inhabitant, gives an interest in the police or regulations of the borough generally; the paying tax gives an interest in the appropriation of the money levied. A right, therefore, to a voice mediately or immediately in these matters, is founded in natural justice. To reject this voice, or even to restrain it unnecessarily, would be wrong. It would be as unjust as it would be impolitic. It is the wise policy of every community to collect support from all on whom it may be reasonable to impose it; and it is but reasonable that all on whom it is imposed should have a voice to some extent in the mode and object of the application. ${ }^{281}$

The first line of democratic principle in Justice Blackenridge's concurrence is that "being an inhabitant, gives an interest in the police or regulations of the borough generally. ${ }^{282}$ This argument may be captured in the phrase "no governance without representation," a democratic precept going back to John Locke, ${ }^{283}$ Thomas

279 See id. at 122.

280 See id. Blackenridge wrote:

Could the legislature have restrained farther without departing from a general principle of almost every corporate body? Even in the monarchical republic of Britain, every individual of that community is supposed to be represented, virtually, as they call it, and to have a voice. I do not believe that a legislature of Pennsylvania, would incorporate with a farther restraint of privilege, unless by oversight. I believe they have not done it. I have not examined at this time; but so far as my memory serves me, there is no incorporation of a borough in which the being an inhabitant for a reasonable time, and the paying a borough tax, does not entitle to a voice for borough officers.

Id.

281 Id. Blackenridge went on to draw a line between the exclusion of aliens from holding public office and the exclusion of aliens from voting: "Reasons of policy may warrant the restraining the eligibility to office, but it must be a strong case of the salus populi indeed, that will warrant the restraining, much less excluding, the right of electing to office." Id.

282 Id.

289 Locke stated:

'Tis true, Governments cannot be supported without great Charge, and 'tis fit every one who enjoys his share of the Protection, should pay out of his Estate his proportion for the maintenance of it. But still it must be with his 
Paine, ${ }^{284}$ and the Declaration of Independence. Here lies the very heart of the democratic idea: that governmental legitimacy depends upon the affirmative consent of those who are governed. Michael Walzer writes: "Men and women are either subject to the state's authority, or they are not; and if they are subject, they must be given a say, and ultimately an equal say, in what the authority does. ${ }^{285}$ A city in which U.S. citizens who vote and hold office govern noncitizens, who do not, is a city very likely engaged in a tyrannical arrangement. For, as Walzer observes, "the rule of citizens over noncitizens, of members over strangers, is probably the most common form of tyranny in human history. "286

The second principle articulated is "no taxation without representation," an argument whose ideological roots can be traced back at least as far as the American Revolution. ${ }^{287}$ The idea is closely linked to the property qualification, since the implicit positive principle it asserts is "representation for all who are taxed," meaning, in the original historical sense, landowners. As originally conceived, municipal corporations were political and economic enterprises in which the landholders owned voting stock. The jointstockholder structure of the municipal corporation made it difficult to justify the disenfranchisement of individual stockholders, or "citizen-proprietor[s]" 288 in Turgot's formulation, on the basis of their nationality. This economic logic for alien suffrage is in fact replete in the historical record. ${ }^{289}$ Today, when taxes are collect-

own Consent, i.e., the Consent of the Majority, giving it either by themselves, or their Representatives chosen by them.

JOHN LOCRE, TWO TREATISES OF GOVERNMENT \$ 140 (Peter Laslett ed., rev. ed. 1963).

284 According to Paine:

I mean that men are all of one degree, and consequently that all men are born equal, and with equal natural right .... [Man] deposits this right in the common stock of society, and takes the arm of society, of which he is a part, in preference and in addition to his own. Society grants him nothing. Every man is a proprietor in society, and draws on the capital as a matter of right.

Thomas Paine, The Rights of Man 38-40 (The Heritage Press 1961) (1791).

285 WALZER, supra note 265 , at 61 .

${ }^{286} \mathrm{Id}$. at 62 . Walzer offers the examples of the Athenian Metics and guest workers in contemporary Europe to describe tyrannical regimes in which those who purportedly are present only for labor purposes in fact "are also subjects. They are ruled . . . by a band of citizen-tyrants." Id. at 58 .

${ }^{287}$ See BAILYN, supra note 272 , at 117, 209-21.

288 SHKLAR, supra note 5, at 36 (quoting KETTH BAKER, CONDORCET 208 (1975)).

${ }^{289}$ See supra notes $277-87$ and accompanying text (discussing democratic principle condemning taxation without representation). 
ed at numerous levels and in many forms, the principle of no taxation without representation would argue for enfranchising the vast majority of aliens, who pay exactly the amount of local property taxes, ${ }^{290}$ federal income taxes, ${ }^{291}$ state income taxes, and state and local sales taxes that they would pay if they were citizens. ${ }^{292}$

\section{B. Objections}

The contemporary relevance of the arguments proposed by Justice Blackenridge in 1809 might be challenged on two separate grounds, one from a republican direction and one from a liberal direction.

The republican challenge would contend that his argument presupposes a common sense of membership and community

290 It might be objected, of course, that the only relevant tax for the purposes of this discussion is the local property tax and that not all aliens own property. But aliens who are tenants, in effect, pay property taxes through their rent. See MINN. STAT. ANN. $§ 290$ A.04 (West 1989 \& Supp. 1992) (“A refund shall be allowed each claimant in the amount that property taxes payable or rent constituting property taxes ...."); see also id. \$ 290.A03 ("'Rent constituting property taxes' means the amount of gross rent actually paid . . . which is attributable ... to the property tax paid on the unit . . . .); OR. REV. STAT. \$ 310.630 (1986 \& 1992 Supp.) ("Rent constituting property taxes . . . . "); Marjorie E. Powell, Note, Resolving the Problem of Undocumented Workers in American Society: A Model Guest Worker Statute, 17 U. MicH. J.L. REF. 297, 300 n.14 (1984) ("Illegal aliens contribute tax revenue through sales taxes and property taxes through rent payments.").

291 See 26 C.F.R. \$ 1.1-1(b) (1992) ("[A]ll citizens of the United States . . . and all resident alien individuals are liable to the income taxes imposed by the Code . . . ."); see also Ambach v. Norwick, 441 U.S. 68, 81 n.14 (1979) ("As our cases have emphasized resident aliens pay taxes . . . ."); United States v. Gonzales, No. 89-F.1740, 1991 U.S. Dist. LEXIS 3087, at *5 n.2 (D. Colo. Feb. 6, 1991) ("All United States citizens and resident aliens must pay federal income tax." ) (quoting 26 C.F.R. § 1.11(b)).

292 The analogy of municipal corporations to private corporations, of course, may be rejected today. The argument is undoubtedly available that localities are no longer thought of as independent and self-governing corporations. See Hunter v. Pittsburgh, 207 U.S. 161, 178-79 (1907) ("Municipal corporations are political subdivisions of the State created as convenient agencies for exercising such of the governmental powers of the State as may be entrusted to them."). See generally Richard Briffault, Our Localism: Part I-The Structure of Local Government Law, 90 CoLUM. L. REV. 1, 85-99 (1990) (" $[\mathrm{A}]$ local government is merely an administrative arm of the state, utterly lacking in autonomy or in constitutional rights against the state that created it."). On this logic, the municipal electorate should presumably be vertically integrated with the state and national electorate. Such an argument does not do justice to the experience or meanings of local democracy and participation. See generally Gerald E. Frug, The City as a Legal Concept, 93 HARv. L. REv. 1059, 1059 (1980) (arguing that the city's powerlessness against the state infringes on people's ability to participate in the decisions that structure their lives). 
among citizens and noncitizens which simply does not exist today. On a critique informed by "a repressive, exclusionary republicanism, ${ }^{293}$ it could be further argued that the community's sense of "social solidarism" today depends precisely on the exclusion of those who are not citizens. ${ }^{294}$ On this reading, the social solidarity that was furnished by property, wealth or race distinctions when alien suffrage existed in the nineteenth century is now provided only by the citizenship requirement. Nothing now successfully binds citizens and aliens together into a common political community.

There are three answers to this argument. The first is that it fairly condemns itself. Arguments for disenfranchisement based on the idea that it will facilitate internal cohesion among the enfranchised are unprincipled. Arguments for disenfranchisement based on the rejected group's insufficient connection to the dominant society are tautological. It is not provable, as an empirical, much less theoretical, matter that members of certain groups have, or do not have, sufficient common interests or values to share a political destiny. Thus, when opponents of inclusion make an argument about insufficient commonality, they are only reinforcing and deepening what they claim to bemoan: the social and existential distance between those on the inside and those outside seeking admission. Moral, social and political community among various groups has never been created in America by isolating people from one another. It is, rather, by including them together in the deliberative political project-which Frank Michelman describes as an "argumentative interchange among persons who recognize each other as equal in authority and entitlement to respect ${ }^{295}$-that a sense of community may be built. Of course, opponents of alien

293 C. Edwin Baker, Republican Liberalism: Liberal Rights and Republican Politics, 41 FLA. L. REV. 491, 505 (1989) (referring to the majority opinion in Lassiter v. Northampton County Bd. of Elections, 360 U.S. 45 (1959) (upholding the lawfulness of literacy tests)).

${ }^{294}$ Frank I. Michelman, Conceptions of Democracy in American Constitutional Argument: Voting Rights, 41 FLA. L. REV. 443, 456 (1989) (describing how Justice Nevius's pro-slavery opinion in the 1845 New Jersey case of State v. Post, 20 N.J.L. 368 (1845), "recalls an early modern, post-feudal world in which visionary social solidarism could present as equality what we see as hierarchy"). Michelman, who has been central to the recovery of the best tendencies in the republican tradition, shows how Justice Nevius mobilizes republican values-" substantive common good, politically grounded rights, deliberative process, political agency constitutive of personal freedom"-to create ideological support for "a solidaristic, and concomitantly hierarchical, sociological vision." Id.

${ }^{295} I d$. at 447 (describing a republican conception of "deliberative politics," contrasted with the liberal conception of "strategic politics"). 
suffrage may actually be seeking to prevent the emergence of such community. As Elizabeth Mensch and Alan Freeman point out, romantic rhetoric about communitarianism and republican character often conceals underlying realities of political domination. ${ }^{296}$

Secondly, we must recognize that the differences between citizens and noncitizens are probably much less significant than we often imagine. The class of resident aliens, to begin with, includes enormously variegated groups in terms of country of origin, reason for emigrating, age, race, income and so on; they are likely to have more in common with particular groups of citizens than they are with each other. Resident noncitizen Irish may identify more closely with Irish-Americans than they do with noncitizen Mexicans, who in turn may inhabit Mexican-American communities but know nothing about Canadian expatriate enclaves in Maine, and so on. Moreover, most immigrant aliens have made important ties to their local communities through marriage, friendship, church, and work.

Finally, aliens are now seen as sufficiently integrated to justify their membership in most intermediate social institutions. As Cass Sunstein notes, "[c]itizenship, understood in republican fashion, does not occur solely through official organs. ${ }^{n 297}$ On this understanding, aliens already participate in numerous forms of citizen action. They occupy university faculty positions, belong to community associations and political clubs, participate in women's organizations, and join (and lead) labor unions under the protection of the National Labor Relations Act. ${ }^{298}$ Alien shareholders in American private corporations have always maintained the right to vote in shareholder elections. This fact is not thought to create any

${ }^{296}$ See Elizabeth Mensch \& Alan Freeman, A Republican Agenda for Hobbesian America?, 41 FLA. L. REV. 581, 599 (1989) (arguing that the "fiction of 'sovereignty of the people' which legitimates a constitutional structure far removed from direct, participatory democracy, serves to perpetuate the illusion that as Americans we really do speak as 'the people,' even though the political reality is far closer to the alienated, transactional world of Dahl (or Hobbes), ${ }^{n}$ and calling for a rejection of romanticism about republican ideals and a direct political confrontation with "our Hobbesian reality").

297 Cass R. Sunstein, Beyond the Republican Revival, 97 YALE L.J. 1539, 1573 (1988).

298 See, e.g., NLRB v. Apollo Tire Co., 604 F.2d 1180, 1181 (9th Cir. 1979) (holding that employed aliens, even undocumented aliens, are "employees" within the meaning of the National Labor Relations Act and as such are entitled to file unfair labor practice claims); Hotel \& Restaurant Employees Union, Local 25 v. Smith, 563 F. Supp. 157, 159 (D.C. 1983) (labor unions legally bound under Act to provide protection to alien members). 
public risk even though the actions of many private corporations affect the national interest far more than the actions of most cities and towns, and even though each municipal inhabitant is confined to one vote while alien shareholders can own a majority of the voting shares of corporate stock.

The second objection to enlisting classical democratic theory on behalf of alien suffrage might accept the liberal rights approach but deny that there is anything tyrannical about citizens ruling noncitizens when the noncitizens have the opportunity to become citizens and members. In the United States, resident aliens may be naturalized after five years if they can demonstrate, inter alia, good moral character and the ability to write and speak in simple English. ${ }^{299}$ It may be argued that this relative ease of naturalization changes the character of governance by citizens over aliens because noncitizens can presumably bring the relationship to a close. ${ }^{300}$ On the other hand, the Athenian metics, whom Michael Walzer discusses, never had the chance to become citizens, nor do many European guest workers today. ${ }^{301}$ These voteless noncitizens choose only between continuing to work without political rights or leaving the host country altogether. By way of comparison, resident aliens in the United States are not permanently locked in a voteless situation.

This argument is not without force, but the tyranny involved in citizen rule over noncitizens is only mitigated, not removed, when a five-year track to citizenship is available. Consider first those immigrant aliens who plan, and have the resources, to naturalize in the shortest possible time of five years: those on a citizenship "fasttrack." ${ }^{302}$ Even five years is a very long time to be voteless, lacking the crucial form of social recognition, in a community in which you live, work, socialize, pay taxes, use public services, and send your children to school. This point is clear from at least three

${ }^{299}$ See 8 U.S.C $\$ \S 1423(1), 1427(a)(3)$ (1988).

${ }^{300}$ See WALZER, supra note 265 , at 61 ("No democratic state can tolerate the establishment of a fixed status between citizen and foreigner (though there can be stages in the transition from one of these political identities to the other)."). Walzer does not address the possibility of extending voting rights for noncitizens, but presumably this practice could be, in his terms, one of the "stages in the transition" from one political identity to the other.

${ }^{301}$ See $i d$. at 58.

${ }^{302}$ See Rosberg, supra note 13, at 1110 (maintaining that those immigrants admitted for permanent residence with the right to live and work anywhere in the United States are resident aliens on a citizenship track). 
legal and constitutional judgments passed on efforts to disenfranchise people for a period of even less than five years.

First of all, courts have repeatedly struck down state policies forbidding college students to register to vote in their campus communities, despite the fact that the majority of college students will only be residents in those communities for four years, if not less. ${ }^{303}$ The courts have emphasized that the four years spent at college are sufficient to generate community attachments and responsibilities. As the Supreme Court of New Jersey stated, college students registering to vote:

are subject to and concerned with not only the state laws and regulations but with the local laws and regulations as well. It is there that they pay their sales and gasoline taxes along with any other applicable charges, it is there that they deal with the local courts and local governmental bodies, and it is there that they are classified as residents by the Census Bureau. ${ }^{304}$

Secondly, in Dunn v. Blumstein, ${ }^{305}$ the Supreme Court struck down, on both equal protection and right to travel grounds, a Tennessee statute confining the vote to persons who had been residents of the state for one year and residents of their county for three months. ${ }^{306}$ The Court rejected the claim that "durational residence requirements are necessary to further a compelling state interest," ${ }^{307}$ and specifically found impermissible "Tennessee's

${ }^{303}$ See, e.g., Williams v. Salerno, 792 F.2d 323 (2d Cir. 1986) (upholding injunction against Westchester County Board of Elections' policy of rejecting college students' voter applications); Whatley v. Clark, 482 F.2d 1230 (5th Cir. 1973) (striking down as a violation of equal protection a statutory presumption that college students have not acquired voting residence in campus home); Hershkoff $\mathrm{v}$. Board of Registrars of Voters, 321 N.E.2d 656 (Mass. 1974) (compelling registration of college students in Worcester and finding that if they have an intention to make their campus residence their home "for the time at least," it becomes their domicile "even if they intend to move later on ..."); Wilkins v. Bentley, 189 N.W.2d 423 (Mich. 1971) (invalidating as due process violation a statute providing that no elector may acquire a voting residence while in school).

304 Worden v. Mercer County Bd. of Elections, 294 A.2d 233, 347 (N.J. 1972) (striking down, in the absence of a compelling state interest, restriction against registration of college students in their campus communities). All of the characteristics mentioned in the text also apply to aliens, including being counted in the Census. See U.S. ConST. art. I, $\$ 2, \mathrm{cl} .3$.

${ }^{305} 405$ U.S. 330 (1972).

306 See id. at 360; see also Carrington v. Rash, 380 U.S. 89 (1965) (striking down on equal protection grounds a provision of the Texas Constitution prohibiting any member of the U.S. armed forces who moved to Texas during his or her military duty from registering to vote there).

${ }^{307}$ Dunn, 405 U.S. at 360. 
hopes for voters with a 'common interest in all matters pertaining to [the community's] government' . . . " ${ }^{308}$ The Court stated:

To paraphrase what we said elsewhere, "All too often, lack of a ['common interest'] might mean no more than a different interest." "[D]ifferences of opinion" may not be the basis for excluding any group or person from the franchise. "[T] $]$ he fact that newly arrived [Tennesseeans] may have a more national outlook than longtime residents, or even may retain a viewpoint characteristic of the region from which they have come, is a constitutionally impermissible reason for depriving them of their chance to influence the electoral vote of their new home State." 309

The argument that durational residence requirements guarantee "the knowledgeable exercise of the franchise," was seriously underand over-inclusive according to the Court. ${ }^{310}$ It stated that such requirements "crudely exclude large numbers of fully qualified people."311

Consider, finally, the enactment of the Twenty-Sixth Amendment in 1971, extending the franchise to eighteen-year-olds. If ever there was a case in which a class of disenfranchised voters could presumably wait their turn to vote, it was surely eighteen to twentyone-year-olds. Members of this class had already won, by statute, the federal right to vote, were guaranteed of voting in state elections on their twenty-first birthdays, and were forced to miss only one, at most two, local election cycles. ${ }^{312}$ But this relatively brief period of three years disenfranchisement was deemed so unfair as to require an amendment to the constitution, a proposition eventually endorsed by thirty-nine states. ${ }^{313}$ A key argument

${ }^{308} I d$. at 355 .

${ }^{309}$ Id. at 355-56 (quoting Evans v. Cornman, 398 U.S. 419, 423 (1970); Cipriano v. City of Houma, 395 U.S. 701, 705-06 (1969); Halls v. Beals, 396 U.S. 45, 53-54 (1969) (dissenting opinion)).

310 Id. at 358.

311 Id. The Court also asserted:

The classifications created by durational residence requirements obviously permit any longtime resident to vote regardless of his knowledge of the issues-and obviously many longtime residents do not have any. On the other hand, the classifications bar from the franchise many other, admittedly new, residents who have become at least minimally, and often fully, informed about the issues.

Id.

312 See Voting Rights Act of 1965, as amended, Pub. L. No. 91-285, 84 Stat. 314 (1970) (amended 1975).

${ }^{313}$ See U.S. CoNST. amend. XXVI; 36 Fed. Reg. 12,725 (1971). 
on behalf of this amendment, ratified during the heyday of youth protest against the Vietnam War, was that the draft age was eighteen: it was often said by the young that those who were old enough to fight were old enough to vote. ${ }^{314}$ This time-honored argument about enfranchising classes of people asked to serve in the military should apply equally as well to aliens, who have been subject, in various degrees, to military conscription ever since it began during the Civil War. ${ }^{315}$

It may still be objected that a great many aliens are not planning to become citizens in the minimum five-year period. At first blush, of course, this fact argues even more forcefully for local alien voting: if it is undemocratic to disenfranchise aliens for a term of five years, surely it is more unjust to disenfranchise them for ten or twenty years. But the point may be pressed that, whether their reasons are economic, political, familial, or psychological, those aliens postponing or foregoing the opportunity to become citizens have cast doubt on the durability of their loyalty or commitment to the local community. ${ }^{316}$

This point is vulnerable to sweeping criticism. Immigration law already provides for deportation of alien persons who engage in espionage, sabotage, revolutionary activity, terrorism, or any conduct that "would have potentially serious adverse foreign policy consequences for the United States." ${ }^{\text {\$17 }}$ Moreover, our constitu-

314 The Senate Judiciary Committee Report issued with the proposed amendment stated, inter alia, that young people had "earned the right to vote by bearing the responsibilities of citizenship." S. REP. NO. 26,92d Cong., 1st Sess. 7(1971), reprinted in 1971 U.S.C.C.A.N. 931, 936.

315 See Charles E. Roh, Jr. \& Frank K. Upham, Comment, The Status of Aliens Under United States Draft Laws, 13 HARV. INT'L L.J. 501, 501-02 n.4 (1972) (noting that in general, "male aliens within the age group designated by the draft laws have been liable for conscription"); see also Neuman, supra note 13, at 306.

316 See Neuman, supra note 13 , at 328.

Unwillingness to renounce a prior citizenship may reflect a wide variety of factors. Sometimes unfavorable economic consequences under the former country's law, such as forfeiture of accrued pension rights or ineligibility to inherit from relatives, may be dominant. Political exiles may wish to preserve the option of return in case of an unlikely change in the character of the regime. Some business immigrants use the United States as a base for international activities, while maintaining close ties with their homelands. Some immigrants expect ultimately to retire to the land of their childhood. Others may have no intention to make practical use of their prior citizenship, but view it as a part of their psychological identity that they are reluctant to renounce.

Id.

3178 U.S.C. $\$ 1251$ (a)(4)(A)-(C) (Supp. II 1990). 
tional regime regards it as presumptively illegitimate to exclude groups of persons from voting because it is thought that they will somehow think or vote differently from the incumbent electorate. ${ }^{318}$ But even assuming that an alien's reluctance to surrender her nationality in accordance with American naturalization law ${ }^{319}$ demonstrates a potential conflict in national loyalties, there is no reason to think that this conflict has any relevance at the local level. While my Canadian or Brazilian neighbors and I may have different interests or approaches on international issues like acid rain or regional trade, we presumably have identical interests in efficient garbage collection, good public schools, speedy road repair, and so on. ${ }^{320}$ Thus, the argument that citizens cannot afford political participation by aliens fades rather quickly at the local level; indeed, citizens may benefit by the increased level of participation in local affairs as aliens come to share the responsibility, not only of following the law, but of helping to shape it. ${ }^{321}$ In this regard, there is every reason to follow the many historical and contemporary precedents of localities (and states) which not only enfranchise aliens but permit them to run for, and hold, public office at the local level. ${ }^{322}$

${ }^{318}$ See Carrington v. Rash, 380 U.S. 89, 94 (1965) ("'Fencing out' from the franchise a sector of the population because of the way they may vote is constitutionally impermissible."). But see Ambach v. Norwick, 441 U.S. 68 (1979) (upholding the constitutionality of a New York statute forbidding the employment as public schoolteachers of aliens who decline to seek naturalization). "Appellees, and aliens similarly situated, in effect have chosen to classify themselves. They prefer to retain citizenship in a foreign country with the obligations it entails of primary duty and loyalty." Id. at 80-81.

${ }^{319}$ See 8 U.S.C. $\$ 1448(a)(2)$ (1988) (requiring all naturalizing persons to "renounce and abjure absolutely and entirely all allegiance and fidelity to any foreign prince, potentate, state, or sovereignty of whom or which the petitioner was before a subject or citizen").

${ }^{320}$ This point was driven home in testimony by representatives of municipalities which have noncitizen voting during hearings on Maryland Assembly Bill 665, which would have forbidden localities to pass alien suffrage. See Testimony by the Village of Martin's Additions Regarding Maryland Assembly Bill 665, at 2 (presented by Sharon Hadary Coyle, Chairperson, Village Council) ("Incorporated municipalities such as ours are concerned with the necessities of daily life-garbage collection, recycling, paving streets, snow removal, tree maintenance, building permits-and for the larger ones, crime prevention. As a municipality, our powers do not extend to national or state-wide policies.") (on file with author).

321 See generally JANE J. MANSBRIDGe, Beyond AdVERSARY DEMOCRACY (1983) (discussing the general benefits of political participation); Carole Pateman, PARTICIPATION AND DEMOCRATIC THEORY (1970) (same).

322 See, e.g., State ex rel. Leche v. Fowler, 6 So. 602, 603 (La. 1889) (finding that alien electors are qualified to hold the public office of coroner); McCarthy v. Froelke, 


\section{Republicanism and Alien Suffrage}

While the democratic argument for alien suffrage has traditionally been formulated in the language of liberalism and natural rights theory, it may also gain momentum from recent interest in the recovery of civic republicanism as a political and constitutional theory. Of course, abstract political theories do not resolve concrete political questions, ${ }^{323}$ and, as noted, republican ideology has often proven quite serviceable for exclusionary and reactionary politics. But its contemporary exponents have been careful to define republican politics as compatible with liberal rights and have pushed the boundaries of republicanism out far enough to make its normative commitments deeply relevant to the question of alien suffrage. ${ }^{324}$ If we can overcome the urge to identify the participatory "citizens" of republican thought with the legal "citizens" of the nation-state, then we can find much of value in the republican revival.

Cass Sunstein has identified four governing principles to which "liberal republicanism" is committed: deliberation in politics (or "civic virtue"), the equality of political actors, universalism and the notion of a common good, and "citizenship, manifesting itself in broadly guaranteed rights of participation. ${ }^{\text {n25 }}$ These principles "are closely related to one another" and all support the develop-

63 Ind. 507, 510-11 (1878) (permitting alien electors in Indiana eligibility to become township trustees); Woodcock v. Bolster, 35 Vt. 632, 640 (1863) (upholding "direct and positive" statutory language extending to aliens the right to vote and "hold office in towns and school districts").

${ }^{323}$ Cf. Lochner v. New York, 198 U.S. 45, 76 (1905) (Holmes, J., dissenting) ("General propositions do not decide concrete cases.").

324 See Sunstein, supra note 297, at 1541 (elaborating a version of republicanism "that is not antiliberal at all"); see also Baker, supra note 293, at 493 (contrasting Michelman's "liberal republicanism" with his own "republican liberalism," which is defined as a liberal conception of rights joined with a republican conception of politics) The best republican scholarship acknowledges that republicanism and liberalism are not two opposite political philosophies but continuous tendencies along several independent axes of political ethics. See Michelman, supra note 294; Morton J. Horwitz, Republicanism and Liberalism in American Constitutional Thought, 29 WM. \& MARY L. REV. 57 (1987). Horwitz asserts:

The argument becomes endlessly complex when one attempts to determine who the liberals and the republicans were in 1789. Even Hamilton and Jefferson will not easily fit the liberal or republican models, as these are only ideal types. These models capture only implicit tendencies, which are, at best, immanent in the thought of any one person.

Id. at 67 .

${ }^{325}$ Sunstein, supra note 297 , at 1541 . 
ment of the person as an equal and active citizen who can participate with others in the common project of local self-determination. ${ }^{326}$ Like Michelman, Sunstein emphasizes the personal constitutive benefits of participation, which he describes as "empathy, virtue, and feelings of community." 327 While there is nothing in this theory inherently requiring the political inclusion of aliens (or for that matter, women or African-Americans), "the renovation of political communities, by inclusion of those who have been excluded, enhances everyone's political freedom. ${ }^{\text {328 }}$

The history of alien suffrage contains one theme which is strikingly consistent with this reconstructed republicanism. Voting by aliens in local elections was often portrayed as a kind of civic education and training for the fuller rights of national citizenship. ${ }^{329}$ The Supreme Court of Vermont emphasized this point in 1863 in deciding, on statutory grounds, that aliens had the right to vote and serve as school committee members in Vermont localities. ${ }^{330}$ The court rejected the argument that it was dangerous to allow aliens to vote in municipal and school board elections because they were ignorant of "the principles and policy of our government." ${ }^{331}$ It stated that, apart from the clear statutory intention to give aliens voting rights, "the objection itself [was un]sound." ${ }^{332}$ Vermont's policy, the court determined, was:

to extend to such emigrants all the rights of citizenship, that their feelings and interests may become identified with the government and the country. While awaiting the time when they are to become entitled to the full rights of citizenship, it seems to us a wise policy in the Legislature to allow them to participate in the affairs of these minor municipal corporations, as in some degree a preparatory fitting and training for the exercise of the more important and extensive rights and duties of citizens. ${ }^{333}$

${ }^{326}$ See id. at $1556-57$.

${ }^{327}$ Id. at 1556.

${ }^{328}$ Frank Michelman, Law's Republic, 97 YALE L.J. 1493, 1495 (1988).

329 See SHKLAR, supra note 5, at 54 (quoting PHILIP S. FONER, LIFE AND WRITINGS OF FREDERICK DOUGLASS 509 (1955) ("Take the ballot from the Negro and you take from him the means and motive that make for an education.").

${ }^{330}$ See Woodcock v. Bolster, 35 Vt. 632, 640 (1863).

${ }^{331}$ ld.

332 Id.

${ }^{333} I d$. at $640-41$. 
The court also saw universal participatory access to the school board as a catalyst for inter-generational involvement with American education. The court stated:

It is of the greatest importance that the children of such persons should be educated, at least to the extent for which opportunity is afforded by our common schools, and that the parents should be induced to send their children to school, and it seems to us that they would be much more likely to do so, and to take interest in their attendance and improvement, if allowed to participate in their regulation and management, than if wholly excluded. ${ }^{334}$

Thus, just as schools furnish a "democratic education" for children, the opportunity to participate in the governance of schools furnishes a "political education" for their parents. ${ }^{335}$ The eloquent logic of this idea may explain why, despite the general demise of alien suffrage in large cities in this century, New York and Chicago permit alien voting in school board elections today. ${ }^{336}$

Our republican inheritance requires us to take seriously not only the principles of no taxation and no governance without representation, but the cultural and educational benefits associated with sharing the vote with all local "citizens." These benefits have to do with the increased dignity and self-esteem which follow not simply from voting, but also from having the right to vote, which is a foundation of social recognition upon which the alien can build. To exclude aliens from the local franchise is not only to deprive them of any political influence over government, but to deny them the benefits of "citizenship as standing."

Like other disenfranchised groups before them, aliens can often experience their life here as "members of a professedly democratic society that [is] actively and purposefully false to its own vaunted principles by refusing to accept [them] or to recognize their right to be voters. "337 Immigrants who have come to the U.S. with great

${ }^{334}$ Id. at 641 .

335 See AMY GuTtMan, Democratic Education 287 (1987) ("Political education prepares citizens to participate in consciously reproducing their society, and conscious social reproduction is the ideal not only of democratic education but also of democratic politics .... .").

${ }_{336}$ See ILL. REV. STAT. ch. 122, para. 34-2.1(d)(ii) (Supp. 1992); N.Y. EDUC. LAW § 2590-c(3) (McKinney Supp. 1993); see also Ambach v. Norwick, 441 U.S. 68, 77 (1979) ("Other authorities have perceived public schools as an 'assimilative force' by which diverse and conflicting elements in our society are brought together on a broad but common ground.").

${ }^{337}$ SHKLAR, supra note 5 , at 14. 
dreams are thus rendered, for the time being at least, politically and socially invisible. Frederick Douglass once said that since democratic government is based on the principle of universal voting, "to rule us out is to make us an exception, to brand us with the stigma of inferiority. ${ }^{n 38}$ To exclude aliens is not only to render them more vulnerable to discriminatory legislation, but to stigmatize them as less worthy than citizens. ${ }^{839}$

\section{Community-Based Democracy and Human Rights:} A Human Right to Local Democracy?

While nationalism prevailed in defining citizenship for voting purposes in the earlier part of the twentieth century, the unification of national economies into a global market system at the end of this century undermines the salience of national identity and increases the historical importance of defining a citizenship of place and locality. ${ }^{340}$ It has become clear that "[c]ities are spatial locations in a globally interdependent system of production and exchange." 341 The new global order is a "web of relations that increasingly synchronizes the lives of people on a global scale. ${ }^{\text {342 }}$ Wherever human beings find themselves living, they face the consequences of this "global web of socioeconomic and political relations. ${ }^{\$ 43}$

338 FONER, supra note 11 , at 75 .

339 The foregoing arguments invite the question of whether local alien suffrage should apply not only to legal aliens but illegal aliens as well. As a theoretical matter, it can be argued that the alien's voting status vis-a-vis the federal government is irrelevant for defining local citizenship. Moreover, the vagaries of immigration law often make lawful resident aliens technically "illegal" for short periods of time. But this position is objectionable because the municipality should respect the decision of the federal government regarding the lawful presence of aliens within the country. As a practical matter, this explosive question is almost certainly much ado about nothing since illegal aliens living in fear of the Immigration and Naturalization Service would never register to vote and thus put their names and addresses on a public document readily available to federal authorities. This last point convinced Takoma Park not to distinguish between legal and illegal aliens, but other municipalities could err on the side of caution by enfranchising "all residents lawfully present and domiciled in the community."

340 On the growing internationalization of domestic economies and its relationship to cities, see generally THE CAPITALIST CrTY (Michael P. Smith \& Joe R. Feagin eds., 1987); Michael Timberlake, The World-System Perspective and Urbanization, in URBANIZATION IN THE WORLD-ECONOMY 3 (Michael Timberlake ed., 1985).

${ }^{341}$ Richard C. Hill \& Joe R. Feagin, Detroit and Houston: Two Cities in Global Perspective, in The CaprTalist CrTy, supra note 340, at 155.

342 Michael P. Smith \& Richard Tardanico, Urban Theory Reconsidered: Production, Reproduction and Collective Action, in THE CAPITALIST CITY, supra note 340, at 87, 92.

${ }^{343}$ Id.; see also Peter H. Schuck, Membership in the Liberal Polity: The Devaulation 
While the globalizing process is fraught with danger for local communities, ${ }^{344}$ a great many cities have taken the offensive by asserting their right to be involved in the conduct of foreign policy and to govern the local effects of international relations. ${ }^{345}$ As Chadwick Alger writes, "people are becoming aware that the intrinsic character of a global issue is that it affects all human settlements. This being the case, it ought to be possible to act on the local manifestation of that issue. ${ }^{\text {n46 }}$ One important example of such action in the United States is the grass roots movement to offer sanctuary to refugees from war-torn countries like El Salvador and Guatemala. ${ }^{347}$

The move towards local noncitizen voting can be seen as part of the trend of communities accepting responsibility for participating in the enforcement of global human rights norms. In this sense, Takoma Park, Maryland, which recently enacted noncitizen voting, was only following up on its earlier decision to make itself a sanctuary city. ${ }^{348}$ After securing the right of Salvadorean and Guatemalan immigrants to live free from war and political persecu-

of American Citizenship, in IMMIGRATION AND THE POLITICS OF CITIZENSHIP IN EUROPE AND NORTH AMERICA 51, 64-65 (William R. Brubaker ed., 1989) ("Transnational economic relationships are ubiquitous, international travel has become inexpensive, migratory pressures are already enormous and are steadily increasing, environmental problems are global, scientific and cultural exchange are highly valued, and political cooperation among nations is more essential than ever before.").

344 See, e.g., David C. Perry, The Politics of Dependency in Deindustrializing America: The Case of Buffalo, New York, in THE CAPITALIST, supra note ?, at 113 (describing Buffalo as a "victim of global economic change" by which industrial production shifts to the Third World, accomplishing a new international division of labor); Saskia Sassen-Koob, Growth and Informalization at the Core: A Preliminary Report on New York City, in THE CAPITALIST CITY, supra note 340, at 138, 151 (detailing the correspondence between economic disparity and the rise in "informalization," the trend toward illegal work and production, subcontracting, industrial homework, and sweatshops).

${ }^{345}$ See Chadwick F. Alger, The World Relations of Cities: Closing the Gap Between Social Science Paradigms and Everyday Human Experience, 34 INT'L STUD. Q. 493, 495 (1990) (noting the "growing efforts in cities to respond to foreign policy issues ... such as nuclear free zones, conversion of military production to peaceful uses, the struggle against apartheid, human rights, and foreign aid."); Shuman, supra note 32 at 158 (1992) (describing and approving the recent growth in community-based democracy which addresses foreign policy).

${ }^{346}$ Alger, supra note 345 , at 505.

347 See id. at 509-10.

${ }^{348}$ See Recommendations of Takoma Park Elections Task Force 1-2 (stating that "Takoma Park's historic commitment to activist democracy and its status as a Sanctuary city" is consistent with "the concept of allowing all residents of Takoma Park, regardless of citizenship, to vote in city elections") (on file with author). 
tion, it extended to them the right to participate in the political life of their new hometown.

Local noncitizen voting may thus reflect important changes in the relevant locus of democratic citizenship. ${ }^{349}$ If the nation-state has been weakened by various global forces and "[c]ommunity-based democracy is sweeping the planet, ${ }^{\$ 50}$ the argument for defining citizenship as nationality and vertically imposing that choice on local governments loses much force. Indeed, the straitjacket of nationstate citizenship may stifle the widely perceived participatory requirements of the time.

In its October 1986 report to the European Parliament, the European Commission argued strongly for allowing all European Community nationals to vote in local elections where they live, regardless of citizenship:

The cornerstone of democracy is the right of voters to elect the decision-making bodies of political assemblies at regular intervals. If the right to vote is to be truly universal, it must be granted to all residents of the territory concerned .... Universality, in the original sense of the word, would imply that all residents, irrespective of nationality, are included in the electorate. ${ }^{351}$

Similarly, the global Non-Governmental Organization Conference released a document in Paris in December of 1991 stating: "It is the natural, and thus universal right of people to partake in decisionmaking that affect their lives, whether these decisions are taken inside or outside their national boundaries." 852 On the other hand, while the Universal Declaration of Human Rights is written in such a way as to leave open the possibility that noncitizens will have the right to vote, the International Covenant on Civil and Political Rights confined the right of suffrage to citizens. ${ }^{353}$

${ }^{349}$ See Robert A. DAHL \& Edward R. TUFTe, Size AND DEMOCRACY 135 (1973) (concluding that the existence of transnational power and sovereignty compels a redefinition of democracy). "Rather than conceiving of democracy as located in a particular kind of inclusive, sovereign unit, we must learn to conceive of democracy spreading through a set of interrelated political systems, sometimes though not always arranged like Chinese boxes, the smaller nesting in the larger." Id.

${ }^{350}$ Shuman, supra note 32 , at 158.

351 Voting Rights in Local Elections for Community Nationals Residing in a Member State Other Than Their Own, COM(86)487 final at 11.

352 Non-Governmental Organization Conference, Draft Citizens Action Plan for the 1990's at 16-17 (1991) (on file with author).

${ }^{353}$ See Intemational Covenant on Civil and Political Rights, G.A. Res. 2200, U.N. GAOR, 21st Sess., Supp. No. 16, at 55, U.N. Doc. A/6316 (1966) (Article 25 states that "[e]very citizen" shall possess voting rights.). 
At any rate, local alien suffrage has made much headway in the last several decades, especially in Europe. In 1975 Sweden adopted voting rights in local and regional elections for foreigners living in the country for three years. ${ }^{354}$ In 1977 Denmark enacted a local alien suffrage policy for Nordic immigrants which has since been extended to give the right to vote and hold local office to all immigrants of three years residence. ${ }^{355}$ Norway changed its constitution to accomplish noncitizen voting in 1978, and now all immigrants of three years residence may vote. ${ }^{356}$ Both Finland and Iceland have extended local voting rights to Nordic citizens. ${ }^{357}$ The Netherlands accomplished local voting rights for all immigrants in the early 1980s. ${ }^{358}$ And, in Switzerland, two cantons have written local alien suffrage into their constitutions. ${ }^{359}$ A local alien suffrage provision has also appeared in the new Constitution of Estonia. ${ }^{360}$

But by far the most ambitious experiment in reciprocal local alien suffrage is contained in the proposed Maastricht Treaty on European Union. ${ }^{361}$ Article $8 \mathrm{~b}$ of the Treaty states that:

Every citizen of the Union residing in a Member State of which he is not a national shall have the right to vote and to stand as a candidate at municipal elections in the Member State in which he resides, under the same conditions as nationals of that State. ${ }^{\mathbf{3 6 2}}$

Although this policy will be limited to citizens of member nations, it would still mark an unprecedented and historic expansion of the

354 Jan Rath, Voting Rights, in THE POLITICAL RIGHTS OF MIGRANT WORKERS IN WESTERN EUROPE 127, 134-35 (Zig Layton-Henry ed., 1990).

355 See id. at 136.

356 See id.

357 See id. at 137.

${ }^{358}$ See id. at 138.

359 See id. at 128.

360 Article 156 of the 1992 Constitution of Estonia provides that in the election of local governments, all persons at least 18 years old "who reside permanently within the territory of that governmental unit" shall have the right to vote). See EsTONIA CONST. ch. XIV, art. 156. There is, of course, an ongoing debate as to whether the new Estonian constitution's citizenship provisions are too strict. See Riina Kionka, Estonia: A Difficull Transition, 2 RFE/RL RES. REP. 89.

361 The Treaty confers citizenship in the Union on all persons "holding the nationality of a Member State." Treaty on European Union, Feb. 7, 1992, art. 8, in COUNCIL OF THE EUROPEAN COMMUNITY, TREATY ON EUROPEAN UNION 15 (1992) [hereinafter Maastricht Treaty]. Unfortunately, the local voting provision contained in Article $8 b$ has apparently elicited criticism in France. See William Drozdiak, Despite Danish Rejection, EC to Pursue Unification, WASH. Post, June 4, 1992, at A22.

${ }^{362}$ Maastricht Treaty, supra note 361, at 15. 
scattered local alien suffrage policies now adopted by individual European states. ${ }^{363}$ Implementation of this Article could spur adoption of similar regional compacts all over the world.

The global push to confer local voting rights on all municipal inhabitants underscores the significance of similar efforts in the United States. As the world grows closer in terms of population mobility, capital investment, labor markets, cultural production, and high technology, it is imperative that we create political norms to make these processes of integration consistent with democratic values. The possibilities for exploiting displaced persons are too great if we make capital and labor mobile but political rights immobile. ${ }^{364}$ We cannot treat the world as a global economic village but define it as a collection of remote islands for the purposes of political participation. Eventually we may define a human right to democratic participation. ${ }^{365}$

\section{TOWARDS A REVIVAL OF AMERICAN NONCITIZEN VOTING}

The United States is home to some ten million ${ }^{366}$ aliens who work in American businesses and government offices, serve in the armed forces, pay local, state, and federal taxes, and are subject to all of the obligations of citizenship, including military conscription. ${ }^{367}$ Since noncitizen voting is neither constitutionally obligatory nor taboo, states and municipalities may approach it as a matter of public policy. ${ }^{368}$ But aliens are not presently permitted

363 See Rath, supra note 354 , at $136-38$.

${ }^{364}$ Michael Walzer has remarked that "[s]tatelessness is a condition of infinite danger." WALZER, supra note 265 , at 32 . We can improve its safety by giving internationally displaced and homeless persons a modicum of local recognition, respect, and influence.

${ }^{365}$ See generally Thomas M. Franck, The Emerging Right to Democratic Governance, 86 AM. J. INT'L L. 46 (1992).

366 See Deborah Sontag, Noncitizens and Right to Vote: Advocates for Immigrants Explore Opening Up Balloting, N.Y. TIMES, July 31, 1992, at B1. The Immigration and Naturalization Service general statistics suggests the number has more than doubled since 1980. In 1991 alone, 1,827,167 immigrants were granted permanent resident status in the United States. See 1991 Immigration and NatURalization SERVICE STATISTICAL YEARBOOK, ADVANCED REPORT (1992).

${ }^{367}$ See Ambach v. Norwick, 441 U.S. 68, 81, n.14 (1979) ("As our cases have emphasized, resident aliens pay taxes, serve in the Armed Forces, and have made significant contributions to our country in private and public endeavors."); Roh \& Upham, supra note 315, at 501 (discussing conscription policy in the United States with respect to aliens).

${ }^{368}$ For municipalities interested in adopting noncitizen voting policies, the threshold question to be answered is whether state constitutional and statutory law 
to vote, or run for office, in any state election, and are therefore shut out from formal political participation at both the state and national level. ${ }^{369}$ There are, however, several important examples of noncitizen voting at the local level which can serve as models for interested localities. Since 1968, New York City has granted noncitizens who are the parents of school children the right to vote and run for community school board. ${ }^{370}$ The City of Chicago

presently permits the extension of the vote in local elections to noncitizens. In some states, such as South Carolina, it will probably be prohibited by the plain language of the constitution. See S.C. CoNST. art. II, $\$ \S 4,5$ (defining state electors as citizens and providing that ${ }^{~}[\mathrm{~m}]$ unicipal electors shall possess the qualifications prescribed in this Constitution"). But in many states, such as Maryland, the constitution and state law is silent on the question of local electoral qualifications, and municipalities can therefore decide to enfranchise noncitizens as an aspect of their constitutional or legislative home rule power. See MD. CONST. art. I (omitting any reference to municipal elections).

${ }^{369}$ Fifty-eight constitutions specify that "citizens" may vote in state elections. See, e.g., HAw. CoNST. art. II, § 1 ("Every citizen of the United States who shall have attained the age of eighteen years . . . ."); IND. CoNST. art. 2, § 2 (same); N.J. CoNST. art. II, \$ 3(a) (same). Whether the language enfranchising "citizens" implies that the franchise is exclusive to citizens and may not be extended to noncitizens by statute could be an open question in some states, but it is definitely intended to be exclusive in other states which replaced constitutional alien suffrage provisions with the citizenship qualification.

The constitutions of Massachusetts and New Hampshire refer to "inhabitants." See MASS. CONST. art. $1, \S 9$ ("All elections ought to be free; and all the inhabitants of this Commonwealth ...") (emphasis added); N.H. CoNST. art. 11 ("All elections are to be free, and every inhabilant of the state . . . ."). Both states, however, have limited the franchise to citizens by statute. See Mass. ANN. Laws ch. 51, $\$ 1$ (Law. Co-op. 1990) ("every citizen"); N.H. REv.STAT. ANN. \$ 654:1 (1986) ("Every inhabitant of the state ... being a citizen of the United States."). There are no reported cases in Massachusetts or New Hampshire in which an alien has sued alleging that her constitutional right to vote has been abridged by statute. In Massachusetts, hostile precedent for such a suit exists in a case in which the Supreme Judicial Court stated that "if the people intended to impart a portion of their political rights to aliens, this intention ought not be collected from general words, which do not necessarily imply it, but from clear and manifest expressions, which are not to be misunderstood." Opinion of the Justices, 7 Mass 523, 525 (1811).

${ }^{370}$ See N.Y. EDUC. LAW § 2590-c(4) (McKinney Supp. 1978-1979) (enfranchising, in community school board elections, registered voters and "every parent of a child attending any school under the jurisdiction of the community board of such district who is a citizen of the state"); see also Ambach v. Norwick, 441 U.S. 68, 81 n.15 (1979) (stating that New York State Education Commissioner has "interpreted the statute governing New York City's unique community school boards to permit aliens who are the parents of public school students to participate in these boards.") (citation omitted); Mary Anne Perez, Quezada's Bid For Noncitizen Vote Debated, L.A. TimEs, Mar. 19, 1992 (Nuestro Tiempo), at 1 (noting that voting eligibility of parents in school board elections in New York city spurs rally by noncitizen parents for enfranchisement in L.A. school board elections). 
similarly gives noncitizens the right to vote in school board elections. ${ }^{371}$

More expansively, a number of smaller localities in the State of Maryland-including Somerset, Barnesville, Chevy Chase Sections 3 and 5, and Martin's Additions-have for decades extended the franchise in all local elections to inhabitants who are not U.S. citizens. ${ }^{372}$ As more intimate communities whose alien populations are apparently composed, in substantial part, of World Bank and embassy personnel working in Washington, D.C., these Maryland jurisdictions rest their policies on both natural rights understandings and the early property-based conception of local voting rights. ${ }^{373}$ It is necessary to note that most of the inhabitants of these small communities tend to share a similar economic and social status which dilutes the threatening image many citizens have of aliens. They also share a physical proximity which permits them to have unrushed and disarming face-to-face encounters with one another. ${ }^{374}$

371 See Ill. ANN. STAT. ch. 122, para. 34-2.1(d)(ii) (Smith-Hurd Supp. 1992) ("Eligible voters ... shall consist of the parents and community residents."); School Board Holds Off On Noncitizen Voters, L.A. TIMEs, Feb. 21, 1992, at B2 ("Noncitizens already exercise voting rights in several cities and states, including Chicago ....").

372 See Beth Kaiman \& Lynne K. Varner, Immigrant Voting Advances in Takoma Park, WASH. POST, Jan. 30, 1992, at M1, M2 (listing Montgomery County communities that do no require voters to be citizens).

${ }^{373}$ For example, the Chair of the Village of Martin's Additions Council gave this testimony before the Maryland General Assembly Committee on Constitutional and Administrative Law:

We believe every resident in our community-regardless of ultimate national or state citizenship-is entitled as a fundamental right to participate in governing our municipal affairs-to have a say in whether we will pave the street in front of his or her house-to influence garbage collection and recycling-and to ensure that the streets are plowed in the winter.

Moreover, the burden is also one of equity, because the residents for whom we argue here, bear responsibilities within the municipality-such as keeping their properties neat and clean, removing snow from the sidewalk in front of their homes, recycling-responsibilities from which they receive no immunity merely because they may not be U.S. citizens. Certainly then, these residents should have a say in how our community will be run.

Further, the fact that many of the non-U.S. citizens resident in our community own their homes and pay property taxes grants them a strong vested interest in maintaining the quality of life in the community in which they have invested.

Hearings on H.R. 665 Before the Maryland General Assembly Comm. on Const. and Admin. Law (1992) (statement of Sharon Hadary Coyle, Chairman of the Village of Martin's Additions' Village Council) (on file with author).

${ }^{374}$ See id. at 2 ("The residents of our small Maryland municipalities feel fortunate to have the opportunity to participate actively in a local political system where the town meeting ethic survives and flourishes. Elected officials are our neighbors . ..."). 
But noncitizen voting in Maryland is not (simply, at least) a naive throwback to nineteenth-century small-town life. For on March 31, 1992, Takoma Park, Maryland, a well-integrated city bordering the District of Columbia with a population of 16,700 , formally amended its municipal charter to give all residents, regardless of citizenship, the right to vote, and run for office, in local elections. The charter change followed several months of excited political debate and controversy which spilled over into the Washington, D.C. area as a whole. ${ }^{375}$ The issue first arose when the Takoma Park Elections Task Force completed its 1990 city council redistricting process. The Task Force found that its new wards had equal numbers of residents, as required by law, but that some wards had far more eligible voters than others because some contained a large alien population. This imbalance focused attention on two facts: the votes of citizens in wards with high citizen populations were worth much less than votes of citizens in wards with high numbers of aliens ${ }^{376}$; and many city residents with all of the obligations of Takoma Park citizenship lacked the right to vote. The Task Force, by and large unaware of the rich history of alien suffrage in the United States, proposed to the City Council that it place on the November 5, 1991 ballot a referendum question on whether the citizens of Takoma Park favored extending local voting rights to noncitizens. On September 30, 1991 the Council voted to place the following non-binding question on the ballot: "Should the Takoma Park City Charter be changed to permit residents of Takoma Park who are not United States Citizens to vote in Takoma Park elections?"377

The referendum debate unleashed its share of xenophobia and prejudice, but the discussion was generally remarkable for its

${ }^{375}$ See Melanie Howard, Ballot Proposes Vote for Aliens, WASH. TIMES, Oct. 30, 1991, at B1. ("The referendum has drawn outside attention to an election that normally would concern only the city of 16,000 , and sparked passionate debate over who has the right to actively participate in government at its most local level. ${ }^{n}$ ).

376 That is, the vote of a citizen in Ward A (with a low alien population) represented a smaller "share" of a Councilmember's electorate than the vote of a citizen in Ward $\mathrm{D}$ (with a high alien population). This disparity clearly violates the principle of political equality which Jonathan W. Still, in an important article calls "equal shares." See Jonathan W. Still, Political Equality and Election Systems, 91 ETHICs 375,378 (1981) (defining "equal shares" as a situation in which each voter has the same share in the election as reflected in "what the voter voted on divided by the number of voters who voted on it").

377 City Council of Takoma Res. \#1991-75 (introduced by Council member Leary) (on file with author). 
sobriety. Advocates of the charter amendment mobilized democratic principles to argue for the change and emphasized the local nature of the proposal. ${ }^{378}$ The Share the Vote campaign worked to humanize the question by bringing to public attention a number of people, who had come to Takoma Park from all over the world and who would be enfranchised by the change. The Washington Post, for example, interviewed Colin Norman, a Washington correspondent for a British magazine and a citizen of the United Kingdom who came to Takoma Park in 1976.

[Norman] says he may be more a part of the city than U.S. citizens who are newcomers to the area. "I have as much interest in the community as anyone he said. ... We're not asking for a voice at the national level or in foreign policy," Norman said. "But in local matters, we're no different than somebody who has moved to Takoma Park from California. ${ }^{\text {"379 }}$

Supporters of the change also observed "an urgent practical side to this idea for those kept out of democracy's circle have other ways of making their grievances known. ... It is better to confront social problems nonviolently in the halls of government than violently in the streets." 380

Opponents of the measure emphasized that illegal aliens would technically be able to vote along with permanent resident aliens. ${ }^{381}$ The former commissioner of the Immigration and

${ }^{378}$ See Jamin B. Raskin, Their Chance to Vote, WASH. PosT, Oct. 13, 1991, at C8. There I stated:

The engine for this continuing democratic expansion is the beautiful principle found in the Declaration of Independence: that governments derive "their just powers from the consent of the governed." The circle of political community must widen to take in all of those governed by the community's decisions. This principle provides the logic for the charter change in Takoma Park.

Id.

${ }^{379}$ Beth Kaiman, Takoma Park Weighs Noncitizen Vote, WASH. POST, Oct. 31, 1991, at M2. George Leventhal, co-chair of the Share the Vote campaign and husband of a noncitizen, stated, "[a] non-citizen is just as affected by the decisions of the City Council as anyone else." Id.

${ }^{380}$ Raskin, supra note 378 , at C8. I noted that:

[The rioting and] blind rage that overtook Mount Pleasant [in Washington, D.C.] this past summer erupted against a background of neglect by the city government that follows from the categorical exclusion of non-U.S. citizens from the franchise. The Latino population of Washington has little political power because it lacks the hard currency in which politicians trade: votes.

Id.

${ }^{381}$ See Howard, supra note 375 , at B1 ("Many of those who [would be] given the 
Naturalization Service argued that alien suffrage "undermines the value of U.S. citizenship" and that five years "is not an unreasonable time to wait to be able to participate in our democracy. ${ }^{882} \mathrm{He}$ also made a slippery slope argument that if local voting by noncitizens is allowed, state and federal voting could be next. Either there is a policy basis for noncitizens to vote, or there is not. If we open the door, it cannot be closed halfway." 383

The November 5, 1991 noncitizen voting referendum passed by a vote of 1,199 to $1,107 .{ }^{384}$ Because the referendum was only advisory, debate continued. But on February 10, 1992, the Takoma Park City Council adopted, by a vote of five to one, a Charter Amendment removing the requirement that voters and candidates for public office in Takoma Park be U.S. citizens in order to participate in the city's biennial elections. ${ }^{385}$ In the meantime, Delegate John Morgan, who represents a district outside of Takoma Park, introduced a bill in the Maryland House of Delegates to prohibit noncitizen voting in local elections. ${ }^{386}$ On February 11, the House Committee on Constitutional and Administrative Law conducted a lengthy and impassioned hearing on the legislation. Bill proponents claimed that noncitizen voting would bring in a tide of unwanted immigrants, while Takoma Park and other noncitizen voting communities argued that this was a local question and home rule should not be invaded. ${ }^{387}$ On March 17,1992 , the bill was

vote are those who have broken the law of the country getting here." (quoting Cameron Whitman of the Federation for American Immigration Reform)); Alan C. Nelson, Undermining Democracy in Takoma Park, WASH. POST, Dec. 8, 1991, at C8 ("[T]he Takoma Park referendum did not distinguish between legal resident aliens and illegal ones."). Charter amendment advocates, however, dismissed this possibility. See Howard, supra note 375, at B1 ("If you were living in the shadows and you were frightened of being captured by the government, you wouldn't register your name on a public document." (quoting Leventhal)).

382 Howard, supra note 375 , at B1.

383 Id.

${ }^{384}$ See Stephanie Griffith, Hispanics Seek Wider Clout in D.C. and Va.: Takoma Park Referendum on Voting Eligibility Spurs Immigrants' Interest, WASH. POST, Nov. 7, 1991, at D6.

${ }^{385}$ See Notice of Amendment to the Municipal Charter of the City of Takoma Park (on file with author).

${ }^{386}$ H.B. 445, 407th Leg., Reg. Sess. (Md. 1993). This bill was introduced January 27, 1993 and assigned to the Judiciary Committee. See In the News: Md. Bill May Thwart Takoma Park Vote, WASH. PosT, Feb. 6, 1992, at M1.

${ }^{387}$ See Hearings on H.R. 665 Before the House of Delegates Comm. on Const. and Admin. Law (Feb. 11, 1992) ("[This bill] threatens to take away our right and that of 5 other municipalities as home-rule governments to make such an important decision.") (statement of Paula Jewell, Takoma Park City Clerk); Letter of Walter 
defeated by a vote of 11-6 and a final local effort to block implementation of the charter amendment fizzled. ${ }^{388}$ On March 31, 1992, Takoma Park became the largest and most recent municipality in the United States to adopt complete noncitizen voting. The move was widely seen as heralding a new movement for local alien suffrage and immediately triggered similar efforts in Washington, D.C., Los Angeles, and New York City. ${ }^{389}$

There are compelling instrumental reasons why municipalities have chosen to embrace the resurgent logic of noncitizen voting. These reasons should also persuade state legislatures to liberalize the home rule power to facilitate enactment of local noncitizen voting laws if it is not presently possible. Like earlier periods in which noncitizen voting was a popular practice, this is a time of heavy immigration. Of course, while immigration was once greatly desired, as at the founding of the Republic, the present immigration is accompanied by much official (and unofficial) ambivalence; encouraging immigration will clearly not be a major part of any renewal of the practice of alien suffrage.

But the people who have joined us on our land are generally here to stay, and the question today is whether they will be democratically integrated and assimilated into our political culture or kept apart as a disenfranchised and increasingly disaffected population. A number of immigrant groups continue to live on the margins of American society. ${ }^{390}$ Recent cases of unrest, delin-

Behr, Mayor of Town of Somerset in Chevy Chase, Maryland (requesting the state to permit them to maintain "a tradition that has worked well for all people in our Town"). Testimony of Sharon Hadary Coyle, Chairperson of the Village Council of Martin's Additions ("We can see no advantage in the State becoming involved in such a minor and local decision-a decision which has no impact at any level above the municipality. ... . We believe the decision to determine voting eligibility in municipal elections should be a local decision ...."). Testimony of Jamin B. Raskin ("This is a decision that rightfully belongs at the local level, for it involves the community's basic right and prerogative of political self-determination.") (on file with author).

${ }^{388}$ See Memorandum from Paula S. Jewell, City Clerk to Takoma Park City Council (Mar. 23, 1992) (declaring invalid for insufficient signatures a petition requesting another referendum on the Charter Amendment) (on file with author).

${ }^{389}$ See Around the Region: D.C. May Give Vote to Noncitizens, WASH. POST, May 7, 1992 at C5 (discussing Ward 1 D.C. Council Member Frank Smith's "legislation ... to grant local voting rights to immigrants who are legal permanent residents and have applied for citizenship"); Perez, supra note 370, at 1 (noting that resolutions by Takoma Park and other jurisdictions have prompted noncitizen parents of L.A. school districts to seek enfranchisement); Sontag, supra note 366, at B4 ("The New York State Assembly's 24-member Task Force on New Americans plans to introduce a bill this summer that will enable municipalities to extend the vote to immigrants who are residents but not citizens.").

${ }^{390}$ See Al Kamen, Myth of 'Model Minority' Haunts Asian American: Stereotype Eclipses 
quency, and riot in immigrant communities, on both the east coast and the west coast, illustrate the dangers of excluding large numbers of people from political membership in their communities. ${ }^{391}$ But it is no answer to say that members of these excluded groups should simply apply for United States' citizenship; their very alienation renders improbable their participation in the citizenship naturalization process, which is more of an affirmation of a sense of social belonging than a first step towards achieving this goal. The virtue of extending the vote in local elections to noncitizens is that it invites noncitizens to participate in, and learn about, American political culture and practices without immediately requiring the greater psychic break of surrendering one's given nationality. Presumably the taste of democratic citizenship that some aliens get from local voting will make them hunger for a greater role in our politics. If so, the practice of alien suffrage, sometimes derided as a threat to the naturalization process, can become once again, as it was in the last two centuries, a pathway to naturalized citizenship.

\section{CONCLUSION}

The old-fashioned democratic principles justifying local alien suffrage may find a new lease on life in the context of globalization of economic and social institutions. As the coherence of the nationstate is increasingly undermined by the global forces of economic and cultural production, the locality may become at once the individual's best hope for meaningful political participation and the world's best hope for counteracting the deracinating and depersonalizing effects of the global economic system. Thus, the traditional democratic arguments for alien suffrage, which are being revived by surges in immigration, are united with the contemporary human rights interest in making the right to participate in politics as mobile as markets for capital and labor. This convergence of local and

Diverse Group's Problems, WASH. POST, June 22, 1992, at A1; Barbara Vobejda, Mexican Americans Stall on Journey to U.S. Mainstream, WASH. POST, June 21, 1992, at A1.

391 See Bill Boyarsky, Leaders Speak, But No One is Listening, L.A. TIMES, May 6, 1992, at $B 2$ (noting that despite large number of immigrants from Latin American and Asian countries in East L.A., they have no representation and little voting power, which generates the kind of resentment expressed in the L.A. riots); Nell Henderson, Power at Ballot Box Eludes D.C. Hispanics: Task Force Attempts To Bridge the Gap, WASH. POST, May 5, 1992, at A1 (discussing a proposal to allow noncitizen vote in response to race riot in hispanic community); Raskin, supra note 201, at B7 ("People frozen out of democracy's circle learn to express their grievances and frustrations in other ways."). 
global democratic pressures argues for making the locality both a polity of presence and a central locus of participatory citizenship.

But my normative argument has elided one central question. Have I proven too much? That is, why do the arguments mobilized on behalf of local noncitizen voting not apply with equal force to voting in state and national elections?

It is admittedly hard to think of any principled way to justify the inclusion of aliens in local elections but their exclusion from state elections. The problem is that the U.S. Constitution categorically makes all persons enfranchised in state legislative elections into federal electors, and alien participation in national elections presents a far more troubling proposition. The exclusionary and adversary definitions which have organized political membership in the nation-state at least since World War I pose extraordinary legal, political, and ideological obstacles to such a plan. It is no coincidence that American alien suffrage fell victim to the political ideology of World War I, which marked the modernization and consolidation of the nation-state system. Before that war, alien voting in national elections was common and quite thinkable; ever since, alien voting in national elections has been non-existent and seemingly unthinkable.

It has been beyond the scope of this Article to query the merits of noncitizen voting in national elections. Suffice it to say that, despite intense globalizing trends in economics, the ideological hold of nationalism has not loosened significantly, and the political interests of nation-states are still essentially organized counter to one another. The idea of having foreign citizens vote in American national elections is thus inherently more troubling than having them vote in local elections. At the local level, each resident's interests in good schools, public services, and transportation are very similar. If these interests diverge at all, it will be according to differences in neighborhood, income, or homeownership-not nationality or citizenship. At the national level, however, American, Mexican, and Canadian citizens arguably have numerous divergent interests as citizens of their respective states.

To make alien suffrage in national elections acceptable to existing nations, it would probably take regional international agreements which provide for reciprocal noncitizen voting arrangements modeled on something like an expanded Maastricht Treaty. It is possible (as opponents of noncitizen voting have already argued) that the spread of local alien suffrage would sufficiently relax the global ideological hold of nationalism as to make people 
all over the world comfortable with the idea of making voting rights mobile between nation-states. ${ }^{392}$ If we ever approach that Kantian moment, when the world becomes an effective confederation of republican nation-states and the right to vote travels with the person, the U.S. Congress will have the Article I authority, under Oregon $v$. Mitchell, ${ }^{393}$ to adopt noncitizen voting as a policy for federal elections and possibly the Fourteenth Amendment enforcement authority under Katzenbach $v$. Morgan ${ }^{394}$ to do the same for state elections. ${ }^{395}$ Needless to say, such a moment is far off in the next century and likely depends upon the prior success of numerous decentralized local experiments with noncitizen voting all over the world. ${ }^{396}$

392 See Alan C. Nelson, Undermining Democracy in Takoma Park, WASH. PosT, Dec. 8,1991 , at C8 (explaining that letting noncitizens vote is a bad idea for reasons of public policy).

393400 U.S. 112 (1970).

${ }^{394} 384$ U.S. 641 (1966).

395 Oregon v. Mitchell established Congress's ample power, under Article I, to define and broaden the federal electorate by adopting eighteen as the voting age for federal elections. See Oregon v. Mitchell, 400 U.S. 112, 293 (1970). In Katzenbach v. Morgan, the Court upheld Congress's authority, under $\$ 5$ of the Fourteenth Amendment, to advance equal protection under the laws by extending the right to vote to all persons who had attended school in Puerto Rico at least through the sixth grade regardless of English language skills. See Katzenbach v. Morgan, 384 U.S. 641, 646-47 (1966). Significantly, the Court recognized this power despite acknowledging that such a rule was not required by $\S 1$ of the Fourteenth Amendment and that New York's law requiring English language literacy was not necessarily in violation of the substantive commands of the Fourteenth Amendment. See id. at 656. Thus, the position that Congress can enforce equal protection by enacting federal and state alien suffrage is not in conflict with the argument made in Part III that $\S 1$ of the Fourteenth Amendment does not require alien suffrage. At any rate, it is abundantly clear from Morgan that Congress could prohibit "the State[s] from denying to [the alien community] the right that is 'preservative of all rights.' This enhanced political power will be helpful in gaining nondiscriminatory treatment in public services for the entire [alien] community." Id. at 652 (quoting Yick Wo v. Hopkins, 118 U.S. 356, 370 (1886)). In Morgan, the Court thus articulated an extremely deferential standard of review for enforcement clause action by Congress. See id. at 653 ("It is not for us to review the congressional resolution of these factors. It is enough that we be able to perceive a basis upon which the Congress might resolve the conflict as it did.") Clearly aliens are a suspect class whose vulnerability in the political system Congress could try to rectify by extending to them the vote. See also Sugarman v. Dougall, 413 U.S. 634, 646-69 (1973) (holding that aliens are a suspect classification).

Alien suffrage at all levels presumably could also be accomplished by way of an international treaty. See LAWRENCE H. TRIBE, AMERICAN CONSTITUTIONAL LAW 226 (2d ed. 1988) ("Under the Supremacy Clause, it is indisputable that a valid treaty overrides any conflicting state law, even on matters otherwise within state control." (citing, inter alia, Hauenstein v. Lynham, 100 U.S. 483 (1880) (upholding a treaty establishing alien inheritance rights over a state law disqualifying aliens from inheriting)).

${ }^{396}$ Reciprocal noncitizen voting may, however, be part of a political program 
But it is possible right now to advance universal suffrage at the local level and push American communities closer to becoming polities of presence. From the beginning of American history, we have maintained that democratic government must rest on the consent of the governed. This principle has always been eloquently articulated but, more often than not, honored in the breach. For, as Shklar writes, "[t]he tension between an acknowledged ideology of equal political rights and a deep and common desire to exclude and reject large groups of human beings from citizenship has marked every stage of the history of American democracy. ${ }^{\$ 97}$

We often imagine the course of the franchise as an ever widening one, progressing seamlessly toward the goals of universal suffrage and popular sovereignty. The history of noncitizen voting provides a potent counter-example to this conception. ${ }^{398}$ But it also provides a challenge to the American political imagination at the close of the twentieth century: can we relax received social categories in order to make the franchise open up once again? Can we come to see the U.S. citizenship requirement for voting in local elections as arbitrary and undemocratic? The question takes us, finally, away from the bright lines and right angles of constitutional theory into the disheveled world of political practice. But the culture of democracy permits a hopeful closing thought: through the acts of memory, empathy, and imagination, what has been undone by history can be recaptured in history, and then remade for new purposes in a new time.

which will soon be necessary to counteract mounting anti-immigrant violence and agitation in various parts of the world. See Ferdinand Protzman, Germany Fears Spread of Rightist Unrest, N.Y. TIMES INT'L, Aug. 28, 1992, at A9 (discussing "nearly a week of anti-immigrant rioting in Rostock, "complete with violence and Hitler salutes, and official fears that "rightist attacks against foreigners were spreading" to other German cities).

${ }^{397}$ SHKLAR, supra note 5, at 28.

${ }^{398}$ Of course, it is not the only counter-example in our history to the myth of linear progression in the franchise. Blacks voted and held office in impressive numbers in the south during Reconstruction, but were quickly disenfranchised thereafter for nearly a hundred years. See FoNER, supra note 11, at 590-92, 604 ("An enduring consequence of Reconstruction's failure, the Solid South helped define the contours of American politics and weaken the prospects not simply of change in racial matters but of progressive legislation in many other realms."); Armand Derfner, Racial Discrimination and the Right to Vote, 26 VAND. L. R. 523, 524 (1973) (discussing the shift away from black enfranchisement during Reconstruction to "total disenfranchisement schemes" between 1890 to 1908, a period that lasted until the modern civil rights movement). But alien disenfranchisement is today's most striking evidence that we have not attained universal suffrage and that not all changes in voting practices are inclusive ones. 